\title{
The economics and institutional economics of wildlife on private land in Africa
}

\author{
Brian A Child ${ }^{1 *}$, Jessica Musengezi ${ }^{1}$, Gregory D Parent ${ }^{1}$ and Graham F T Child ${ }^{1,2}$
}

\author{
* Correspondence: bchild@ufl.edu \\ ${ }^{1}$ Stellenbosch Institute for \\ Advanced Studies (STIAS), \\ Wallenberg Research Centre at \\ Stellenbosch University, Marais \\ Street, Stellenbosch 7600, South \\ Africa \\ Full list of author information is \\ available at the end of the article
}

\begin{abstract}
In southern Africa, there are now 10,000 to 14,000 private ranchers that promote wildlife enterprises alone or in some in combination with domestic livestock. An important conservation success, this new bio-experience economy also creates social well-being through economic growth and job creation. It is an economic sector that needs to be taken seriously, not least because it pioneers policies that inform the valorization and sustainable management of ecosystem services. The article describes the historical emergence of a sustainable use approach to wildlife conservation since the Arusha Conference in 1963. It suggests that indigenous multi-species systems may have ecological advantages over modern livestock production systems, but these are difficult to quantify in complex dryland ecosystems and are trumped by economics and political processes. However, wildlife provides the foundation for a bio-experience economy that has a decided comparative economic advantage over agro-extractive commodity production (like beef) in drylands. We describe how new policy approaches, especially the valorization of wildlife and the devolution of proprietorship to landholders and communities, have allowed wildlife's economic advantages to be reflected in land use decisions through both 'game ranching' and 'community-based natural resource management'. Institutional changes have modified the economics of wildlife in drylands, promoting both conservation and development by allocating environmental raw materials to higher-order goods and services. A further goal of the paper is to describe practical economic methods for assessing and explaining the wildlife sector to policy makers in terms of its profitability, both to individual landholders and to society through jobs and economic growth. The paper covers a 50-year period between the PhD studies of the four authors and takes a trans disciplinary approach which values the knowledge of practitioners as much as the academic literature.
\end{abstract}

Keywords: Wildlife economics, Wildlife conservation, Game ranching, Sustainable use, Southern Africa

\section{Review}

\section{Background}

This provides a review of the economic evolution of the private wildlife sector in southern Africa since the 1960s. It is intended to be accessible to a wide readership (not just economists or wildlife managers). It draws on the academic literature but also on considerable practitioner knowledge networks including gray and oral literature. It describes the history of the wildlife sector from the perspective of the economic principles and lessons that are emerging from this policy experiment. Our purpose is to

\section{焦 Springer}

(c) 2012 Child et al.; licensee Springer. This is an Open Access article distributed under the terms of the Creative Commons Attribution License (http://creativecommons.org/licenses/by/2.0), which permits unrestricted use, distribution, and reproduction in any medium, provided the original work is properly cited. 
describe the evolution of a sustainable use (or neo-liberal) approach to wildlife management (SASUSG 1996; Martin 2009), which is underrepresented in the literature relative to alternative paradigms of conservation and development.

We evaluate the economics of wildlife using the private sector experience for methodological reasons, although this economy is smaller than the wildlife economy based on Africa's protected areas, less scalable to Africa's extensive drylands than community-based wildlife management, and under political scrutiny because of its racial history. However, stronger property rights and a gradual shift from administrative to free-market competitive pricing mean that pricing is less distorted and economic evaluation is more reliable on private land. Evaluating the economics of drylands is difficult at the best of times because internalizing the full costs and benefits of resources like water, grazing, and wildlife is complicated because they are fugitive in space and time, while ecological processes such as carbon and water cycles and soil processes are complex and nonlinear, making the attribution of costs and benefits difficult.

The political economy of natural resources further muddies the economic waters. Historically, wildlife has been monopolized (e.g., protected areas) and heavily regulated by the state, and market signals violate many of the assumptions needed for a sound economic analysis given the recent and partial shift from centralized planning to market-based approaches. Wildlife also coexists with pastoralists and subsistence farmers who are politically marginalized, with limited and contradictory rights (e.g., of exclusion and use) to natural resources. Thus, economic signals are distorted by a combination of state monopolies, regulation, administrative pricing, weak institutions and/or predatory governance, and confused or open-access property regimes, making economic analysis near impossible. 'Market failure', an economic term that refers to the gap between the actual price of a good and its real value, is pervasive.

On private land in southern Africa and, indeed, where private land exists elsewhere in Africa's drylands, the shift from livestock to wildlife is widely acknowledged but not reliably quantified. There are reported to be some 9,000 'game ranches' in South Africa alone plus over 15,000 which combine wildlife with livestock (Cousins et al. 2008). The rapid expansion of the wildlife sector mirrors the growth in the regional and global bio-tourism industry and is reflective of shifting global terms of trade. The South African game ranching sector has expanded at between 5\% and 20\% annually in the last decade, whereas real farm incomes have declined by 5.3\% (Dry 2010a, b; Jenkins 2011). Game ranching is a diverse sector that combines ecotourism, the sale of live animals, several forms of hunting, and as a by-product, meat production. Prime wildlife areas generate large amounts of income and employment from tourism, while trophy hunting is geographically more extensive and a reliable form of income where wildlife populations are recovering or in areas of limited tourism potential. Hunting is critical in the transition from cattle ranching back to multi-species production systems, except where large amounts of capital are available for restocking, because it utilizes only $2 \%$ to $3 \%$ of wildlife populations that can biologically expand at $10 \%$ to $30 \%$. The markets for hunting also appear to be larger and more robust than is often assumed, and both the supply and price of trophy animals has been rising steadily in southern Africa since the mid-1970s (Booth 2002, 2009; Lindsey et al. in press). For example, elephants sold for US dollars $\$ 250$ in the late 1970 s and are now worth $\$ 12,000$ to $\$ 20,000$ in trophy fees and up to $\$ 65,000$ when we include outfitter fees. This suggests that upscaling of 
trophy hunting and ecotourism is possible without tumbling prices. The southern African wildlife sector is a tiny share of the global tourism and hunting market, and tourism is a cluster industry that benefits from economies of scale and from trends in global terms of trade. By contrast, beef commodity prices have been stagnating globally for nearly four decades (albeit with a significant upturn in the last two years). Beef production has also shifted steadily away from the drylands since the 1960s following technological 'advances' like grain feeding, nitrogen supplementation, and feedlots, while Africa's drylands are unlikely to be competitive with large-scale meat production in Argentina, Brazil, or the USA.

Land use trends on private land, together with the data summarized in this paper, confirm that the bio-experience economy based on the multiple uses of wildlife is an increasingly serious industry. It is beginning to be included in national agricultural statistics, especially in South Africa, though it is not yet well quantified because of its diversity compared to commodity markets. As an example of the magnitude of this sector, private land hunting alone is worth over US \$one billion in South Africa. Even the casual observer can see that Africa's famous protected areas have significant impacts on the growth of nearby urban centers like Arusha (Tanzania), Kasane, Maun (Botswana) as well as national capitals.

The purpose of this paper is to present the case for wildlife as a profitable form of land use in semiarid savannas, creating more jobs and economic growth than meat commodity production. For ecological and economic reasons, the bio-experience economy is a legitimate development option. With a more favorable policy environment, it could be applied on a much broader scale than is currently the case, especially if it can be adapted to Africa's communal area circumstances through approaches like community-based natural resource management. Furthermore, these economic advantages are increasing. Global terms of trade are moving in favour of the bio-experience economy; the wildlife sector is a new industry with considerable potential for adding value through product diversification and development, and it is synergistic with ecosystem services like water and carbon that are as undervalued as wildlife was several decades ago.

In focusing this paper on presenting the economic case for wildlife, we are not taking an 'either-or approach' to economic alternatives. Our aim is to maximize the well-being of people living in marginal areas in environmentally sustainable ways, with wildlife conservation contributing to this in areas where it has a comparative advantage. Nonetheless, we cannot avoid the implications that meat commodity production through livestock or wildlife is economically and environmentally questionable in drylands. White minority regimes supported cattle ranchers with significant subsidies for several decades, but when these were removed in the transition to black majority rule, the beef economy in drylands was shown to be financially marginal and ecologically hazardous, and many of these landholders only survived by adding or switching to wildlife operations (Child 1988; Grossman and Gandar 1989).

Unlike beef commodity production, traditional livestock systems have multiple values (e.g., milk, meat, cash, and store of value). This may give them financial and ecological advantages, but in the absence of recent or detailed long-term studies of these systems that include the costs of labour and environmental capital, we are safer to assume that they are unlikely to outperform commercial systems by a factor of two. In other words, 
their viability is still questionable, and we are irresponsible if we do not question the assumption that dryland animal production can meaningfully address poverty. While we claim no expertise in pastoral economics, our livelihood surveys (unpublished data) from Shorobe and Sankuyu communities in northern Botswana suggest that household poverty is higher, and income distribution far more skewed, in communities that depend on livestock (Shorobe) than those with wildlife (Sankuyo). Additional data from communal lands in South Africa (see below) suggest that the economic output communal land is low. While beyond the scope of this paper, rural people in the drylands of southern Africa are vulnerable to extreme poverty and appear to be surviving more on wages, remittances, and government transfer payments than on local production. Generally speaking, livestock are kept primarily for cultural reasons and as a mechanism of savings and coping with risk. It is also significant that they are an asset that can be privately owned and used to harvest natural resources in situations where people generally have limited rights to valorize, manage, or exclude others from 'their' natural resources. This paper is about the wildlife economy and its potential to drive development.

The challenge of scaling up this economic model and adjusting it to the livelihoods of the rural poor in Africa's communal drylands moves beyond the economic model itself to the challenges of transferring it in difficult political, institutional capacity and demographic circumstances. This policy response in southern Africa has been labeled community-based natural resource management (CBNRM). Since the mid-1980s, CBNRM has attempted to replicate the economic success of wildlife on private land in the complex institutional circumstances of Africa's communal areas (Martin 1986; Metcalfe 1993; Jones and Murphree 2004; Child and Barnes 2010) by attempting devolving full rights to use, manage, and benefit from wildlife to communities as had been done for private game ranchers (Murphree 1994), albeit falling short of this intention (Martin 2009). On the one hand, it is naïve to suggest that wildlife can resolve poverty for millions of people in drylands, but on the other, CBNRM has clearly benefited both people and wildlife where it has been implemented with some level of competence (Child et al. 2003; NACSO 2006). However, in several countries where superior wildlife resources could clearly benefit people, this has not occurred (Nelson and Blomley 2009; Nelson 2010). We fall on the side of the debate that the problem lies more with implementation than with the model itself (Hulme and Murphree 2001), which often falls far short of best practice because communities are not really empowered to use, manage, and benefit from wildlife (or for most natural resources that matter) (Martin 2009; Ribot et al. 2010).

Although strongly associated with wildlife, CBNRM in southern Africa can be interpreted as a new institutional model that links payments for ecological services to poverty reduction (Child 2004a, Frost and Bond 2008), which is applicable to many ecosystem services, but just happens to take advantage of the value of wildlife and opportunities that arose because wildlife provided an institutional greenfield. We certainly need such models. Ecosystem services have been valued at several times global gross domestic product (GDP) (Costanza et al. 1997), but we seldom take this into account in land use decisions. Indeed, the challenge of our generation may well be to internalize the costs and benefits of ecosystem services in the livelihoods and land use decisions of the rural people who coexist with biodiversity in the manner that has been attempted for wildlife. For example, the models of micro-governance and household cash payment 
systems developed in some community wildlife programs (Child 2004a, b, 2006) are currently being replicated with REDD payments in Tanzania (Morgan Brown, personal communication). In other words, wildlife provides both a valuable resource for many drylands and also a new model with economic, institutional, and governance components that may be transferable to other natural resources and ecosystem services. This paper addresses only the economic component of this approach.

\section{New approaches to wildlife conservation}

Beginning in the 1950s, conservationists in southern and East Africa began to develop a new paradigm for conservation based on sustainable use of natural resources (SASUSG 1996). Leading this policy experimentation was private game ranching, especially in southern Africa. Although this has been a highly successful conservation and economic initiative, relatively little is published about it or about the economic research, methods, and principles behind this growth. Private wildlife conservation or 'game ranching' strongly influenced the new vision of conservation and development that arose to prominence during the 1980s and 1990s (Martin 2009). The basic message of the sustainable use approach is that wild resources and ecosystem services are enormously valuable. If we change the ways that we govern them and if we can place landholders and rural communities at the junction of benefit and management, wild resources can pay for themselves and simultaneously address rural poverty and environmental injustice. At the time these ideas were introduced, they were radical, encompassing three major conceptual strands (Hulme and Murphree 2001):

- that the state should devolve proprietorship, including the responsibility for and benefits from managing wild resources, to the landholders and the communities that live with them;

- that natural resources should be exploited sustainably and as profitably as possible to achieve both conservation and development goals; and

- that the neo-liberal concepts of markets, property, and exchange should play a greater role in shaping incentives for conservation and allocating resources to their highest valued uses.

Game ranching provides an example of how practitioners simplified a plethora of principles into one overarching guiding statement: 'to maximize the benefits from wildlife to the people on whose land it lives' (Child 1995). It is also an example of the centrality of institutions or the formal rules or informal norms that frame human conduct (North 1990) to the relationships between people, economy and nature, and the process of modifying these institutions in ways that were insightful, carefully crafted (Borgerhoff Mulder and Coppolillo 2005), and changed the outlook for wildlife in Africa.

\section{Brief history of wildlife use}

We can view the wildlife economy in four phases (Table 1). In the pre-modern economy, wildlife was plentiful, and the primary constraint to use was the technology and costs of harvesting it. This was followed by a 'frontier economy' associated with the Industrial Revolution and the exploration and settlement of Africa by Europeans. New technology and markets, including guns, wagons, and even railways, radically altered 
the economy of wildlife and enabled hunters to harvest vast numbers of wildlife at a low cost to sell in new urban and global markets. In the absence of institutions for controlling offtake, wildlife, including North America's vast herds of bison, was decimated in a classic case of market failure whereby individuals internalize benefits but externalize costs to society.

In response to this, wildlife was nationalized. In 1900 and 1933, the European powers met in London to respond to the perceived extirpation of wildlife in their African colonies, making three policy decisions with long-lasting implications (Heijnsbergen 1997). First, they encouraged the formation of state protected areas, which led to the formation of Africa's spectacular national parks and now support vibrant economies when managed effectively. Second, they greatly restricted the commercial use of wildlife, rendering wildlife valueless except for low-value subsistence uses. Third, they centralized ownership of wildlife in the state, disenfranchising landholders and taking upon themselves the burden of protecting wildlife from people (anti-poaching) and protecting people from wildlife (problem animal control). In some countries, local communities were severely disenfranchised, especially where traditional methods of hunting were made illegal and ownership of firearms was restricted (Carruthers 1989; Brockington and Igoe 2006). But in others, like Zambia and Botswana, local people were given considerable freedom to hunt under permit systems that often became difficult to administer (Astle 1999).

The policy response embedded in the 'London Convention' became widely accepted, sometimes dogmatically, as the way conservation should be done: a combination of 'pristine' parks and non-utilization of wildlife on land outside them, with wildlife as a priceless but commercially valueless asset, funded by the state and managed on its behalf by a small band of dedicated game rangers. However, by the late 1950s, population growth and the rapid spread of agriculture and livestock were causing an inexorable decline of Africa's unique and spectacular wildlife. At the twilight of colonial Africa, many leading conservationists met at the Arusha Conference on the 'Conservation of Nature and Natural Resources in Modern African States', emphasizing that a radical new approach was needed to conserve wildlife (IUCN 1963). This, the delegates said, needed to be led by Africans, and wildlife needed to become an economic asset according to the emerging 'use it or lose it' philosophy. Thus, the opening comments of the conference proceedings emphasize:

Only by the planned utilization of wildlife as a renewable natural resources, either for protein or as a recreational attraction, can its conservation and development be

Table 1 Phases in the political economy of wildlife

\begin{tabular}{ll}
\hline Phase & Features \\
\hline 1. Pre-modern economy & - Use is limited by ability/costs of harvesting \\
2. Frontier economy & - Costs of harvesting greatly reduced by technology. \\
& - Profits increased by markets. \\
& - But few rules or norms to control use \\
3. Wildlife is nationalized & $\cdot$ Control of wildlife centralized in the state \\
4. Sustainable use approach & - Commercial use greatly restricted \\
& $\cdot$ Use of wildlife devolved to landholders (and later, to communities) \\
\hline
\end{tabular}


economically justified in competition with agriculture, stock ranching and other forms of land use (p19, IUCN 1963).

The emergence of wildlife utilization

Conservationists began to argue that wildlife was better suited to using Africa's harsh environments than the domestic monocultures imported from Europe because, to quote again from the Arusha Conference, the variety of ungulate fauna, their mobility, high standing biomass, and greater nutritional efficiency is seen to give them advantages over domestic livestock that concentrate their attention on a single constituent of the plant standing-crop biomass - the graminacious carpet (p19, IUCN 1963). Nonetheless, by 1980 fully, some 95\% of the large herbivore biomass in southern Africa was livestock (Cumming and Bond 1991).

The 1950s and 1960s saw unprecedented research into the ecology of wildlife, its meat production potential, and even domestication (Talbot et al. 1961; Talbot et al. 1965; Mossman 1975). Cropping schemes were initiated, mostly in East Africa, and well-known conservationists like George Adamson and others (in Kenya), and Norman Carr (Zambia) proposed schemes whereby local people would benefit from wildlife (IUCN 1963; Parker 2004). The United Nation's African Special Project was developed to assess and invest in the potential for wildlife as an economic tool in Africa (Riney and Hill 1967), including the establishment of national parks and game reserves (e.g., Botswana) and cropping schemes (e.g., Luangwa Valley, Zambia). However, with the transition from colonial to African rule in East Africa, the control of wildlife was increasingly centralized (Kabiri 2010), and policy momentum shifted to southern Africa where there was considerable discussion about the potential value of wildlife (Riney 1960; Dasmann 1964), and experimental game cropping was initiated (Dasmann and Mossman 1961). By the late 1960s, the heads of wildlife agencies in southern Africa began meeting annually through the 'Standing Committee for Nature Conservation and the Management and Use of Wildlife' of the 'Southern African Regional Commission for the Conservation and Utilization of the Soil'. Soon thereafter, we see legislation emerging in Namibia, Zimbabwe, Mozambique, Botswana, and South Africa's provinces allowing landholders to use their wildlife commercially and with far fewer stateimposed restrictions (Child 1971; Suich and Child 2009). When it became apparent that permits and surveys were impractical and that landholders husbanded valuable wildlife just as they husbanded their domestic stock, regulatory requirements were reduced. In Zimbabwe, they were virtually removed by the bold Parks and Wild Life Act of 1975.

\section{Ecology and commodity (meat) production}

Early research and discussions focused on wildlife's ecological adaptations to Africa's climate and diseases (Mossman 1975) and the ability of wildlife to produce more meat, or better quality meat, than livestock (Talbot et al. 1965). It suggested that wildlife produced high-quality meat but that the logistical challenges of cropping free-ranging wild animals reduced potential profits. Research then turned to the relative suitability of diverse multi-species production systems compared to livestock monocultures. In elegant studies, ecologists noted how the diversity of wildlife was matched to the diversity of vegetation and threats from predators (Jarman 1973), and that semiarid savannas in particular evolved under indigenous multi-species systems typically carrying 15 to 25 
ungulate species compared to a maximum of five domestic species (Cumming 1982; Cumming 1995). Scientists were surprised at how much overlap there was in the dietary preferences of wild herbivores, but it was also argued that diet separation and the fact that gregarious wildlife was invariably mobile helped to maintain ecological balance, especially between the woody and grass components of savannas (Taylor and Walker 1978; Child 1995). Ecologists noted that production in many African rangelands was water limited (Coe et al. 1976; Bell 1982) and emphasized the importance of the grass layer in absorbing rainfall and making it available to plants (Kelly and Walker 1976). 'Degradation' was thought to be synonymous with the loss of perennial grasses, which maintained the structure of the soil surface and absorbed water (Riney 1963; Walker 1987). Overgrazing or frequent incorrect burning of the grass layer could tip the crucial balance between grass and trees (Riney 1963; Mahesh Sankaran et al. 2005) into a new (and less productive) stable state from which recovery was difficult (Campbell and Child 1971; Walker et al. 2004).

Important and interesting as this research was, researchers were marching down a blind alley in comparing the relative ability of wildlife and livestock to produce meat. The meat productive potential of semiarid rangelands was ecologically limited, regardless of species. Increasing animal production reduced the health of the grass layer (and water infiltration where water was the limiting factor), thus undermining itself. In other words, meat production was ecologically limited, and attempts to move beyond these limits ultimately failed as we see later with private beef ranching in Zimbabwe. Ultimately, the solution lay not in choosing between wildlife and livestock for meat production but in adding value in ways that was not directly linked to extraction from the environment, such as experiences or luxury goods like trophy animals. Seen retrospectively, wildlife scientists mistakenly thought in terms of commodity production (like the agricultural agencies of the time) rather than improving the economic allocation of resources to add value. In the end, institutional adaptation and the development of new markets by farmers, not production technology, provided commercial solutions for ranchers through a shift from agro-extractive beef commodity production to a bioexperience economy.

\section{Dysfunctional legal systems and human-wildlife relationships}

In the twentieth century, white settlers acquired land in southern and East Africa, and African agriculture and populations grew rapidly. Prior to World War II (WWII), the new conservation laws were directed mainly at white commercial hunters, and local hunting for the pot was usually overlooked (Parker 2004). But as rural populations grew, local hunting began to threaten wildlife, was increasingly treated as poaching, and prosecuted by the state. Criminalizing a traditional livelihood strategy like hunting created a powerful sense of injustice, especially when enacted by colonial governments that lacked political legitimacy. 'Poachers' became Robin Hoods and were protected by their communities, so wildlife laws were difficult to implement. This also created a negative relationship between local people, wildlife, and the state.

Setting the state up against the people was never likely to result in sustainable solutions for wildlife. In pre-independence Zimbabwe, for instance, protectionist conservation alienated white farmers from wildlife and became an important political tool in the hands of black nationalists by highlighting the injustice of white minority rule. Even today, some national wildlife agencies expropriate the benefits of wildlife for themselves 
and their cronies and treat local 'poachers' brutally, so pastoral people who are natural allies of wildlife, are planting fields in important wildlife areas, mostly to protect their land rights (Nelson 2010).

One outcome of these dysfunctional policies is the false impression that local people hate wildlife. Our surveys of local people across southern Africa show that people are often extremely concerned about the impact of wildlife on their crops and livestock (and the ineffective management of this problem), yet over $90 \%$ of people claim to like wildlife (or to like it a lot) for both aesthetic and material reasons. What they do not like, however, is the inequity of wildlife laws and the high-handed manners of officials who implement them; they like wildlife, and even protected areas, but not the wildlife officials or laws. This situation is beginning to improve with the advent of CBNRM in countries like Namibia and Botswana.

Protectionist, centralized wildlife legislation, from urbanized and wealthy industrial nations, was politically unjust and economically flawed, causing enormous losses of wildlife in developing, rural societies after WWII as agriculture expanded. The 1940s to the 1970s were the heyday of agriculture. Cattle ranchers complained that 'you cannot farm in a zoo' and wildlife was steadily exterminated (Taylor 2002). Newspaper clippings in Zimbabwe dramatize cases where cattle ranchers shot large numbers of wildebeest and zebra and (having no legal commercial use) left them to 'rot in the veld'. However, the bigger threat was more subtle: the fencing of water points and livestock overgrazing eliminated wildlife for lack of food and water.

\section{The perspectives and contributions of private landholders}

We use a series of case studies to describe the shift back to wildlife, which began slowly led by a few maverick cattle ranches and then accelerated into a landscape-wide phenomena. In the Lowveld of Zimbabwe, for example, the late George Style of Buffalo Range Ranch (20,000 ha) had a penchant for wildlife. From the mid-1950s, he developed a successful cattle business, fencing paddocks and providing artificial water. The eastern section of his ranch was bounded by the Chiredzi River, which for decades provided wildlife and livestock with permanent water in the dry season (Figure 1). Consequently, this part of the ranch (some 9,000 ha) was degraded, and George Style experimented with wildlife as much as a hobby as for commercial reasons. Browsers like eland, kudu, and impala thrived, and the sensitive grazing species like sable, roan, and Lichtenstein's hartebeest displaced by cattle began to recover. Style culled impala to be sold through his butcheries and soon (early 1970s) initiated 'mini-safaris' with foreign hunting clients in a well-appointed hunting camp.

George and his son, Clive, encouraged the use of their ranch for comparative research. Detailed vegetation transects showed that cattle grazing damaged perennial grasses and the soil surface, largely because of the continuously high stocking necessary to keep a beef enterprise viable, whereas the range was slowly recovering under wildlife (Taylor and Walker 1978; Child 1988) (Figure 2). Overstocking appeared to directly damage range productivity, with the pattern of cumulative overstocking (i.e., stocking rate in each year less predicted carrying capacity calculated from rainfall using the formula from Coe et al. 1976) matching a rapid decline in cattle calving rates (Child 1988) (Figure 3) and ultimately destroying the profitability of the livestock enterprise on Buffalo Range. This experience was shared by many cattle ranchers in the Lowveld (PriceWaterhouse 1994; Taylor 2002), who began to switch to wildlife enterprises, some 


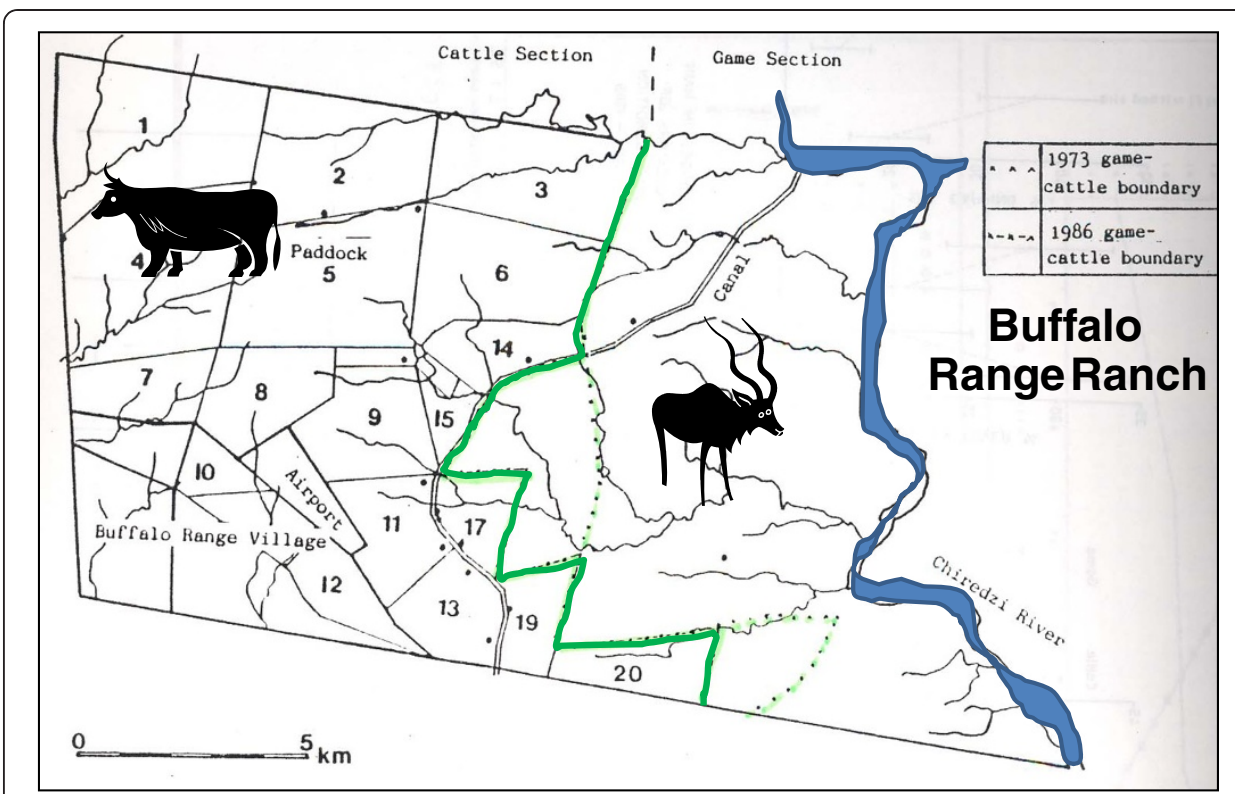

Figure 1 Map of Buffalo Range Cattle and Game Ranch.

partially, some completely, and some as groups of landholders over large blocks of land, especially after losing livestock in the severe droughts of 1984 and 1992 (Taylor 2002; Lindsay et al. 2009).

\section{The beginnings of safari hunting on private land}

On most properties, the switch to wildlife was gradual. Many cattle ranchers survived financially by using remnant populations of wildlife for safari hunting. With good revenues and few overhead costs, wildlife initially supplemented cattle ranching, but later, some ranchers switched over entirely. Hunting guests from North America or Europe stayed with the rancher for seven to ten days, initially in a spare bedroom and later in specially built accommodation. Each day, they would go out early in the morning or in the late afternoon, shooting roughly one animal a day. These were called 'plains-game
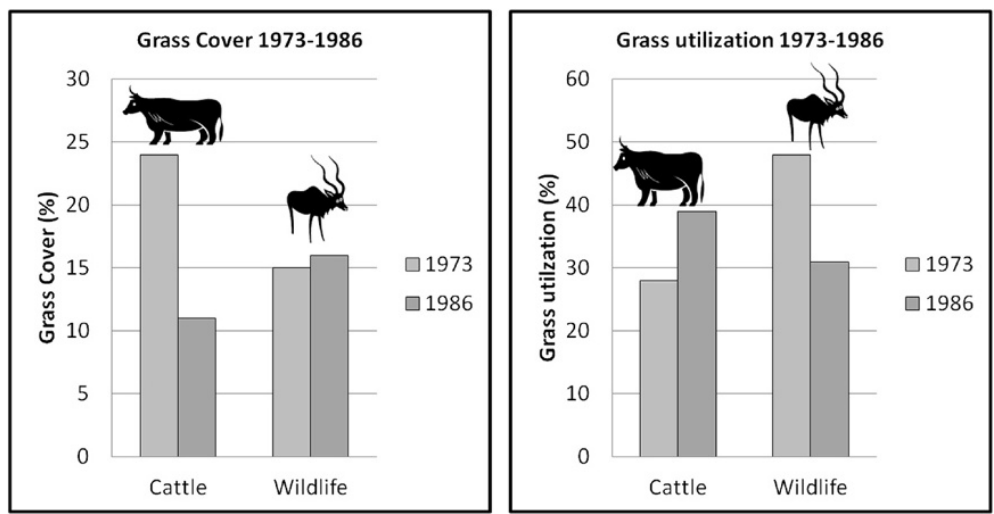

Figure 2 Changes in grass cover and grazing intensity on Buffalo Range ranch between 1973 and 1986. 


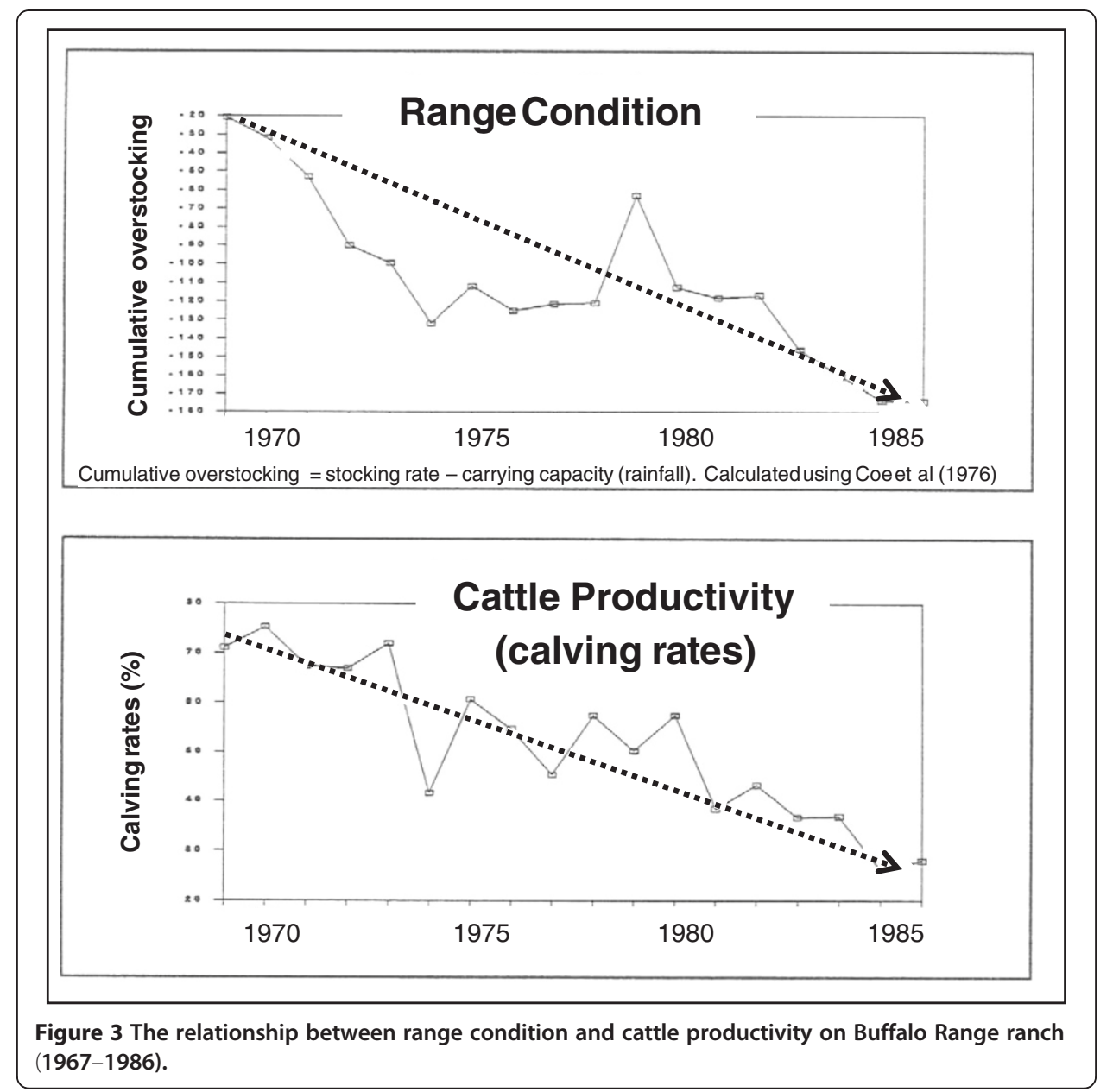

safaris' because they relied on species like kudu, zebra, wildebeest, impala, and warthog. Ranchers then improved their hunting product by nurturing or reintroducing valuable species like eland, sable, waterbuck, and even predators like leopard, and later by adding big game like elephant and buffalo, usually as part of multi-property conservancies. But to do this, they began to improve environmental management by reducing stocking rates and habitat fragmentation by removing cattle fences and scaling up to multiproperty management units. Cattle ranchers like George Style spent many days in the field hunting and developed considerable knowledge about the habits and needs of wildlife, which spread through farmer field days. Under natural conditions, wildlife is highly mobile to respond to highly variable savanna rainfall, and ranchers defragmented their land with simple (and cost-saving) measure like removing one strand from conventional four-strand cattle fences, allowing species like kudu and eland to jump over them, and wildebeest and warthog to duck under them. Similarly, they stopped fencing water points and modified conventional cattle water troughs to enable wildlife to drink. They catered for the specific needs of valuable species like sable, which struggle to compete with cattle, and managed diseases like 'snotsiekte' (malignant catarrh) by ensuring that their cattle were separated from wildebeest at calving time, during which transmission from wildebeest to cattle occurs. 
Trophy hunting is sustainable; meat production very risky

Although it runs counter to the moral argument, hunting animals for meat should not be encouraged whereas killing them for sport provides a powerful conservation tool. The recovery of wildlife over much of southern Africa has gone hand-in-hand with trophy hunting, which is a robust, low-risk solution for two reasons: (1) the mathematics of population biology and (2) the transparency of safari hunting markets. An offtake of $2 \%$ to $3 \%$ provides a steady supply of quality trophy males compared to population growth rates of $10 \%$ to $30 \%$, so ranchers like George Style made good profits from safari hunting at the same time when wildlife populations recovered rapidly. Trophy hunting (unlike meat production) is profitable and ecologically robust, even more so because trophy hunting markets are personalized and information-rich, so hunting clients quickly avoid outfitters who over-hunt with below-average trophy (horn) size. Indeed, the ecological challenge on successful game ranches like Buffalo Range is seldom too little wildlife, but too much. George Style culled hundreds of impala to protect the environment and allow greater diversity of wildlife even though game meat production seldom covered costs.

In contrast to safari hunting, which is ecologically robust and profitable, commercial or subsistence wildlife meat production is ecologically risky and economically questionable. Meat is a ubiquitous low-value commodity without the market checks and balances associated with hunting trophies. We need to kill at least 20 times as many animals to generate the same income from meat as from trophy hunting, and the costs are much higher. On private land, bushmeat is seldom viable except as a by-product of more lucrative hunting and tourism businesses, with the implication that bushmeat poaching is viable only because the harvester externalizes many costs to society. The safest conclusion is that meat production in drylands, either from livestock or wildlife, is seldom viable if the full financial and environmental costs and benefits are accounted for. It has not succeeded on private land, and we extend economic models based on bushmeat production to rural communities at our peril.

\section{Developing an economic understanding of wildlife production}

Trophy hunting is worth more than a billion dollars in South Africa alone (Flack, personal communication), yet data and publications on private wildlife conservation in southern Africa are sparse. The purposes of this section are to summarize, with increasing sophistication, methods used to understand the economics of the private wildlife sector, to influence policy making in the past 25 years, and to use case studies to illustrate how the wildlife sector has emerged.

Shortly after Zimbabwe's Independence in 1980, one of the authors (Brian Child) was recruited by the wildlife department to conduct economic research and extension on game ranching (1984 to 1989). By spending extensive time with game and cattle ranchers, he gained their confidence, learned how much they knew about wildlife, and worked with them to understand the economics of their wildlife and livestock enterprises. Data from 22 cattle ranchers at the wetter limits of rangelands in the Zimbabwean Midlands in 1984 (Vincent and Thomas 1961) showed that safari hunting was easily the primary wildlife activity, with income comprised as follows: guiding (35\%), trophy fees (46\%), meat from trophy animals (13\%), and meat cropping (7\%). All but one of these landholders was primarily a cattle rancher. 
Gross income (turnover) and net margins (profits)

Livestock, which comprised $80 \%$ of herbivore biomass, generated most of the income in the area (Table 2), but when variable costs were deducted, livestock profits were (Zimbabwean dollar) Z\$4.52/ha compared to Z\$2.93 from wildlife. All values for Zimbabwean research are stated in 1984/86 Z\$ when US\$1=Z\$1.3 A new financial ratio (i. e., profit/kg livemass) that we invented to reflect the ecological reality that grass was the limiting factor (see above) showed that, from $1 \mathrm{~kg}$ of livemass, wildlife earned 17c and cattle earned 7c, suggesting that, at the margin, it paid landholders to reallocate grazing from livestock with wildlife. A similar survey of 15 properties and 446,818 ha in the more arid Lowveld in 1986 (including Buffalo Range Ranch) confirmed that it was economically rational to switch land from livestock (earning 7c/kg livemass) to wildlife (26c) (Table 3).

Repeating a survey of rancher opinions (unpublished mimeo) about rancher opinions about wildlife in the Zimbabwe Midlands ten years after the radical Parks and Wild Life Act of 1975 (that devolved full authority to landholders to use wildlife), and only four years after the civil war ended, showed significant changes. Wildlife income had quadrupled, and neutral or negative attitudes towards wildlife decreased from $22 \%$ to $0 \%$. In line with the predictions of the sustainable use approach, the geographic range of valuable hunting species increased, as we also see in the data from South Africa (see below). The number of properties utilizing reedbuck, bushbuck, wildebeest, zebra, waterbuck, tsessebe, kudu, eland, and sable increased by $21 \%$; the geographic range of these species expanded by $22 \%$, and that of the most valuable species (i.e., waterbuck, tsessebe, eland, and sable), by $35 \%$. In terms of biodiversity conservation, a single, sedentary, gregarious bulk-roughage feeder (i.e., domestic cattle) was replaced by a spectrum of 15 or more species of wild (and domestic) animals (Child 2009), and habitats noticeably improved (personal observation, photographs) on large unfenced ranches in Zimbabwe, although there were strong concerns about degradation on small fenced game farms in South Africa.

By the late 1980s, most cattle ranchers in Zimbabwe began to promote and use wildlife because of a decline in cattle prices and subsidies and increasing ecological problems highlighted by the 1984 and 1992 drought. A significant number shifted completely into wildlife, especially in southern Zimbabwe and near Hwange National Park and Victoria Falls. An excellent documentary video about the formation of the Save Valley Conservancy illustrates these broader trends (Taylor 2002). In the video,

Table 2 A financial comparison (in Zimbabwean \$ dollars) of wildlife and livestock in the Zimbabwean Midlands in 1984

\begin{tabular}{|c|c|c|c|}
\hline \multicolumn{4}{|c|}{ Wildlife and livestock economics in the Zimbabwe Midlands } \\
\hline & Units & Cattle & Wildlife \\
\hline \multicolumn{4}{|c|}{ Comparison/unit area (wildlife $=20 \%$ of biomass) } \\
\hline Income & $\mathrm{Ha}$ & $\$ 13.57$ & $\$ 3.36$ \\
\hline Profit (income - variable costs) & $\mathrm{Ha}$ & $\$ 4.52$ & $\$ 2.93$ \\
\hline \multicolumn{4}{|l|}{ Comparison/kg biomass } \\
\hline Gross income & $\mathrm{Kg}$ & $20 c$ & $20 c$ \\
\hline Profit & $\mathrm{Kg}$ & $7 c$ & $17 \mathrm{c}$ \\
\hline
\end{tabular}


Table 3 A financial comparison (in Z\$ dollars) of wildlife and livestock in the Zimbabwe Lowveld in 1986

\begin{tabular}{lcccc}
\hline \multicolumn{4}{c}{ Cattle and wildlife profitability in the Lowveld in 1986} \\
\hline & Livemass $(\mathbf{k g})$ & Turnover $(\mathbf{Z})$ & Profit $(\mathbf{Z})$ & Profit $/ \mathbf{k g}$ \\
\hline Cattle & $10.1 \mathrm{~m}$ & $\$ 2.0 \mathrm{~m}$ & $\$ 0.7 \mathrm{~m}$ & 0.07 \\
Wildlife & $4.7 \mathrm{~m}$ & $\$ 1.4 \mathrm{~m}$ & $\$ 1.2 \mathrm{~m}$ & 0.26 \\
\hline
\end{tabular}

$\mathrm{m}=$ million.

one of the leading ranchers in the Lowveld (Clive Stockil) describes how cattle ranching had been developed in the areas since the 1950s. Following the adage 'you can't farm in a zoo', wildlife had been steadily replaced, including through active elimination campaigns (e.g., of buffalo) by the veterinary department. Footage shows the degradation of the habitat (much as described for Buffalo Range) and the collapse of cattle enterprises. Noting that ranching needed to be ecologically sustainable, economically viable, and socio-politically acceptable, Stockil describes how 27 ranchers studied the situation. They commissioned a report (PriceWaterhouse 1994) that concluded that wildlife would double their income and increase the return on capital from $1 \%$ to $3 \%$ (beef) to $10 \%$ to $22 \%$ (wildlife). Consequently, the 27 landholders in the Save Valley shifted from livestock to wildlife, combining 344,200 ha of previously degraded cattle ranches into a huge wildlife conservancy with no internal fencing and common management policies (Lindsay et al. 2009). The Save Conservancy was systematically restocked with elephant, buffalo, predators including lions and wild dogs, and many of the antelope species displaced by livestock. Hunting and tourism lodges diversified the economy, generated more profits, provided more jobs, and allowed the environment to recover. To all intents and purposes, this resembled a private national park. At least seven other similar initiatives occurred in Zimbabwe at the time.

\section{Kickback from single commodity Leviathans}

By the late 1980s, the relative economics of wildlife and livestock had reversed, but agricultural polices had not. Despite falling beef prices on the world market, government veterinary and agricultural agencies continued to support beef while imposing considerable costs on the wildlife sector to the detriment of private ranches and the greater economy (Muir-Leresche and Nelson 2000) although wildlife was enabling cattle ranchers to stay on the land (a pattern also observed in Texas, personal observation) and to recover its ecological function (Child 1988; Jansen et al. 1992; PriceWaterhouse 1994). But powerful government agricultural agencies continued to promote beef without considering its impact on wildlife, illustrating the dangers of single-sector decisionmaking. Between 1919 and the 1980s, thousands of wild animals including rhinos were shot in the name of tsetse fly control (Child and Riney 1987), hundreds of miles of game fence were erected, habitats were grossly modified including the bulldozing of riparian woodlands and waterholes, and DDT and deildrin were applied on a broad scale. In the 1980s, large areas of the country were further fenced to control foot-and-mouth disease despite questions as to the technical and economic merits of a fencing solution (Taylor and Martin 1987). Based on controversial evidence of buffalo-to-livestock transmission, all buffalo on private land were shot despite the veterinary department being informed that buffalo could double the profitability of wildlife enterprises. To combat this, the small wildlife department began to study the economics of the cattle sector 
Table 4 Quick and dirty beef industry budget (Zimbabwean \$ dollar 1986)

\begin{tabular}{lc}
\hline Costs & \\
\hline 1. Government services & 62 \\
2. Cold Storage Commission subsidy & 50 \\
3. Farmer's variable costs & 74 \\
4. Farmer capital investment (land, cattle) & ?? \\
5. Farmer overhead costs (fixed costs) & ?? \\
6. Industry investment in European Union-standard abattoirs, buffalo fencing, etc. \\
7. Environmental costs (overgrazing) & ?? \\
Total Costs & $185+$ \\
Income & 149 \\
1. Actual & 191 \\
2. With European Economic Commission exports & \\
\hline
\end{tabular}

and developed a quick and dirty 'budget' for the beef sector (Table 4). Financial data compiled from government reports (Child 1988) showed that even preferential access to the high-priced European Union market would not cover farmer and industry costs, even before the fixed costs to farmers (e.g., capital value of livestock, land, and facilities), the industry (e.g., costs of new EU compliant abattoirs), or the environment were accounted for. Single-sector Leviathans emphasized commodity production (e.g., bags of maize and kilograms of beef) with little appreciation of economic issues like comparative advantage or allocative efficiency, which may speak well to politicians but does not maximize societal well-being.

A historical review of the government's own reports, including Parliamentary Commissions of Inquiry, showed that the beef sector had been heavily subsidized for several decades through advantageous beef prices, wealth transfer from the peasant to

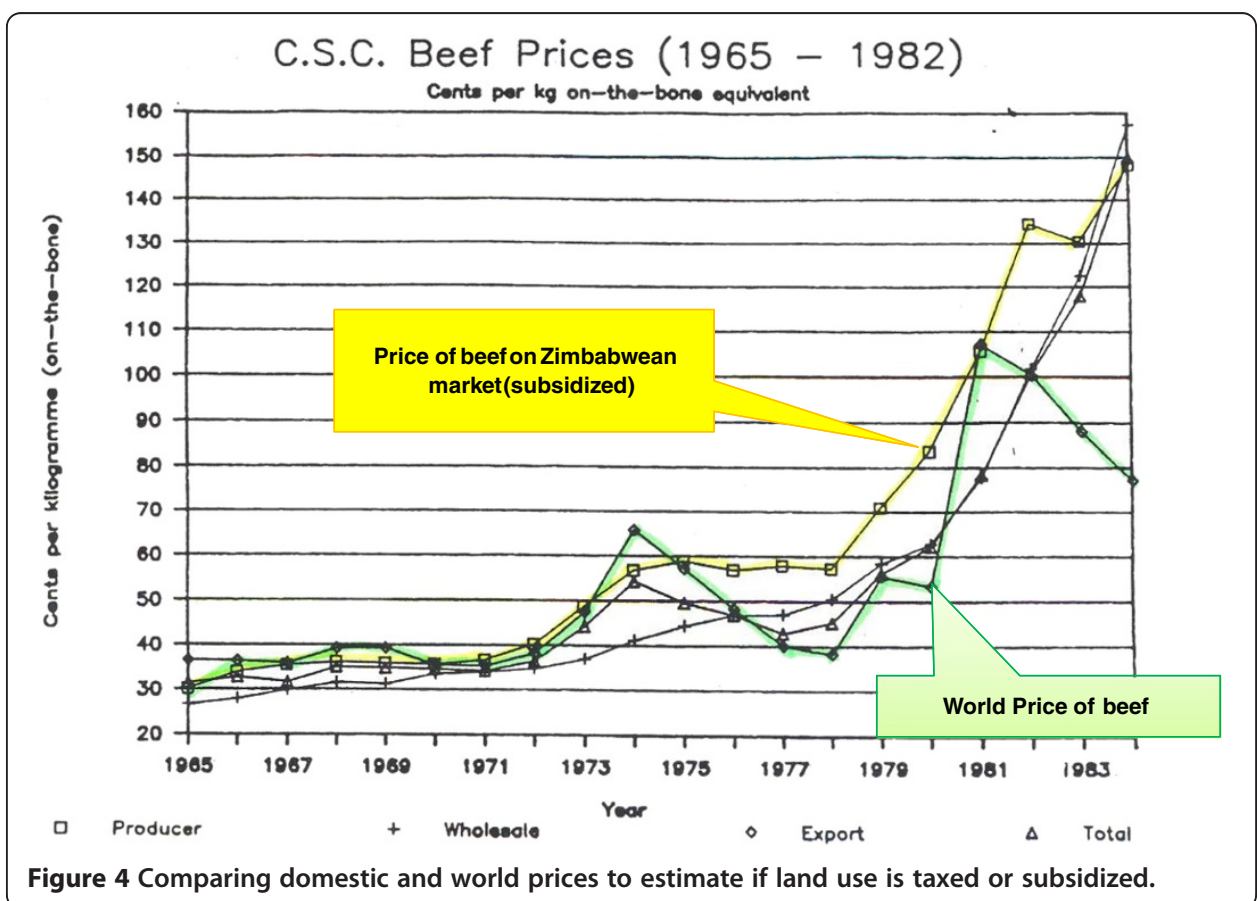


commercial herd, support to farm development through fencing and water provision, subsidisation of single-channel marketing systems (the Cold Storage Commission), and so on (Phimister 1978; Child 1988). Methodologically, developing these arguments is time consuming and subject to different interpretations. Parity pricing provides a quicker and more reliable method for assessing if beef producers are subsidised (or taxed) by comparing the price farmers get for beef on the domestic market compared to the world market. Using government statistics (Figure 4) reveals that, after the mid1970s, the domestic price of beef was on average 40\% higher than the world price, confirming other research findings that producers were heavily subsidised through pricing policies (Williams 1993).

\section{Financial and economic analysis}

The proponents of wildlife intuited as far back as the 1960s that wildlife was being displaced by livestock despite being a better land use option. An economist would say that wildlife had an inherent comparative advantage in drylands but was undervalued by market failures so that scarce resources were being misallocated to the detriment of society. In 1990, World Wide Fund for Nature (WWF) and Zimbabwe's wildlife agency used detailed financial accounts and asset registers to assess the viability of some 150 cattle and wildlife enterprises (Jansen et al. 1992). Wildlife was more profitable than livestock, with only $5 \%$ of livestock operations generating a return on capital in excess of $10 \%$ when profits were calculated using market (financial) prices (Figure 5). Market prices were then adjusted to remove pricing distortions caused by market failures. In terms of societal outcomes, wildlife was even more profitable (Figure 6), providing jobs, economic growth, and foreign currency (which was undervalued by governmentcontrolled exchange rates). The rapid transition towards wildlife in many areas, unfortunately, was never accurately quantified, but judging from trophy sales, wildlife populations on private land quadrupled between 1984 and 1992 (Booth 2002).

\section{South Africa and Namibia}

The land invasions in Zimbabwe in 2000 undermined much, but not all, of this progress. However, similar trends on private land in Namibia, South Africa, and Botswana confirmed the coming of age of the wildlife bio-experience sector. In Namibia, between the early 1970s and 2001, livestock populations on private land halved from 1.8 million

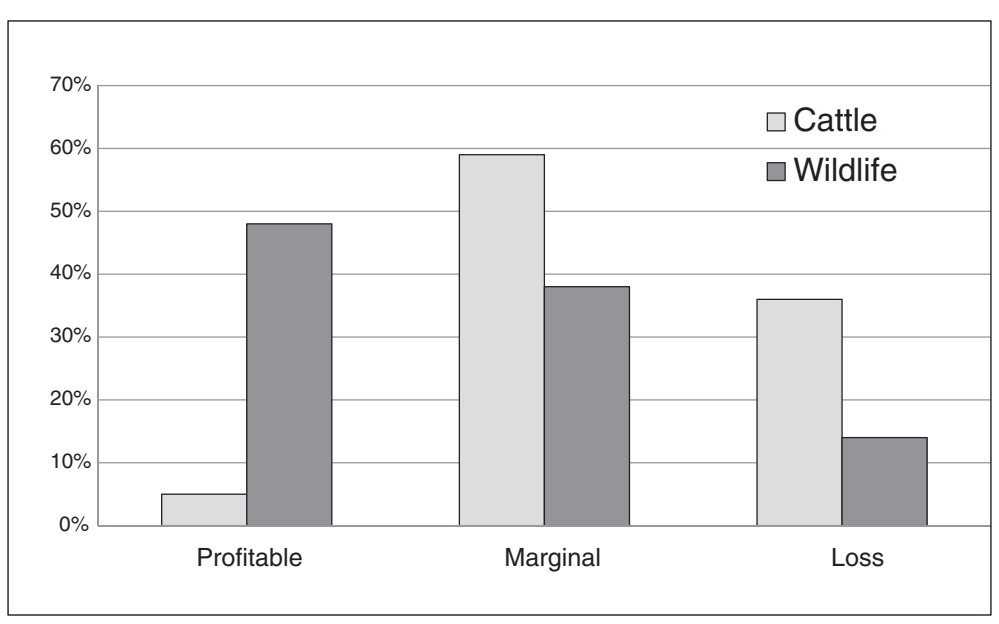

Figure 5 Comparison of the financial profitability of cattle and wildlife in Zimbabwe in 1990. 


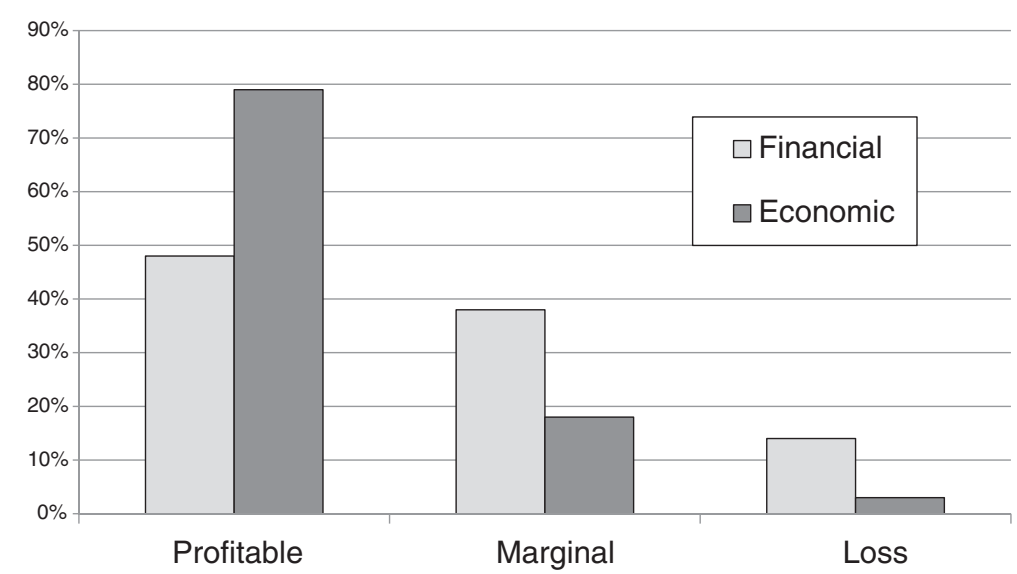

Figure 6 Comparison of the financial and economic profitability of wildlife in Zimbabwe in 1990.

to 0.91 million, whereas 'huntable' wildlife populations doubled from 0.565 million to 1,161 million head for economic reasons (Barnes and Jones 2009). In South Africa, the numbers of wild animals easily quadrupled between 1964 and 2005, with some sources (Flack unpublished data; Carruthers 2008 suggesting as many as 18.6 million wild animals between 1964 and 2005, and there are now some 10,000 wildlife ranches and some 4,000 mixed wildlife and livestock enterprises (Bothma et al. 2009). Private wildlife areas expanded eightfold between 1979 and the mid-1990s (Chadwick 1996), protecting at least $16.8 \%$ of the total area of South Africa (Cousins et al. 2008) compared to $6 \%$ as IUCN category I to IV protected areas. As with Zimbabwe, 'utilized' species increased much more rapidly than those 'protected'. Rhino increased from 50 to 18,000 , and black wildebeest from a few to 26,000, much faster than bontebok (few to less than 5,000) and Cape Mountain Zebra (few to 1,200) for which hunting has only been allowed within the past decade (Flack, personal communication).

\section{Policy analysis matrix}

Despite its size and economic importance, there is remarkably little research or political economic understanding of the wildlife sector in South Africa and some risk that conservation, economic, and employment gains will be undone in the politically charged debate over land restitution. We highlight key findings of an investigation of the economics of game ranching near Kruger National Park (Musengezi 2010) and illustrate the usefulness of the Policy Analysis Matrix or PAM methodology (Table 5).

The PAM is theoretically robust (Monke and Pearson 1989), relatively easy to apply, and useful for influencing policy makers, especially in finance ministries because it is easy to understand as it follows the basic calculation, profit = income from sales less

Table 5 Policy Analysis Matrix (PAM)

\begin{tabular}{lcccc}
\hline & Revenues & \multicolumn{2}{c}{ Costs } & Profits \\
\cline { 2 - 4 } & & Tradable inputs & Domestic factors & \\
\hline Private prices & $\mathrm{A}$ & $\mathrm{B}$ & $\mathrm{C}$ & $\mathrm{D}$ \\
'Social' (or 'economic') prices & $\mathrm{E}$ & $\mathrm{F}$ & $\mathrm{G}$ & $\mathrm{H}$ \\
Divergence & $\mathrm{I}$ & $\mathrm{J}$ & $\mathrm{K}$ & $\mathrm{L}$ \\
\hline
\end{tabular}

'The PAM can also account for environmental externalities and for ecological, regulating and social/cultural services by building estimates of the cost of these into social prices, but we did not do this. 
costs of production. Constructing a PAM requires social skills because it relies on landholders' providing their income and expenditure accounts. It also requires technical skills to classify accounts into revenues, tradable and domestic factor costs, and to calculate 'economic' prices. It can be extended to incorporate negative externalities on ecosystems or social/equity systems and to guard against ignoring these in policy recommendations. The PAM is particularly useful for assessing if a land use represents a good choice for society and how much choices are being distorted by policy and market failures.

In this paper, for example, we use PAM to assess if wildlife is an optimal use of drylands, that is, does wildlife have a comparative advantage? 'Comparative advantage' is not the same as absolute advantage but explains why countries gain mutually from trading in products for which they have relative efficiencies. Comparative advantage is calculated by comparing value-added (i.e., revenues-tradable inputs) to the costs of local land, labour, and capital (i.e., domestic factors), which is why the PAM split costs into two columns: tradable inputs and domestic factors.

Second, we can calculate how much market and policy failures are distorting prices, and therefore land use decisions, away from the real values that would guide private actors to allocate resources efficiently for society. We quantify these price distortions by comparing private prices (top row) to prices in perfect markets (social prices row), correcting prices using various econometric techniques. The divergence between the private and social prices is a measure of the magnitude of market failure. It is also a critical economic concept with considerable implications for conservation policy. When private prices diverge from their true values, private decision makers do not properly internalize social benefits and costs of their actions. This causes under-provision or over-utilization of natural resources and is the root of many natural resource problems (Libecap 2009).

In 2010, Jessica Musengezi applied the PAM methodology to eight properties near Kruger National Park in South Africa (Table 6). Wildlife enterprises were too diverse (and innovative) to summarize using simple averages. Property (a), for example, supported high-end tourism charging over US $\$ 500$ per night, while property (d) was purchased for ecological reasons and profits were an insignificant objective. Only property (g) still had livestock, but profitability was achieved from vertical integration including an abattoir and butcheries (providing profits far in excess of cattle ranching in the area).

Simple gross income and net margin (i.e., gross income - direct costs) data showed that all wildlife properties (except (d)) are profitable (Table 6), exceed the returns from extensive commercial beef production (according to models provided by the Department of Agriculture), and provided significant numbers of jobs (Musengezi 2010). Indeed, wildlife enterprises create more jobs than the livestock enterprises they displaced by a factor of two and as much as five, and these jobs are also more specialized, increasing wage bills some 20- to 32-fold, (PriceWaterhouse 1994; Taylor 2002; Langholz and Kerley 2006).

We illustrate how the PAM is used to assess the relative economics of wildlife production using Farm (a). The capital letters in the formulas are defined in the PAM in Table 5. At a basic level, Farm (a) generates (South African rand) R8,706 /ha and is 'profitable' after costs with a gross margin of R8,282 (US\$1=R7). It also adds value to 
Table 6 Summary of PAM results for eight wildlife properties in South Africa in 2010

\begin{tabular}{|c|c|c|c|c|c|c|c|c|}
\hline \multirow[b]{2}{*}{ All price in South Africa Rand } & \multicolumn{8}{|c|}{ Farm } \\
\hline & a & b & c & d & e & $f$ & g & $\mathrm{h}$ \\
\hline \multicolumn{9}{|l|}{ (US $\$ 1=\mathrm{R7})$} \\
\hline \multicolumn{9}{|l|}{ Property attributes } \\
\hline Farm size (ha) & 5,207 & 1,700 & 3,700 & 2,017 & 2,800 & 3,200 & 14,400 & 30,000 \\
\hline Big five & Yes & No & Yes & No & No & No & No & Yes \\
\hline Beds & 68 & 42 & 52 & 12 & 12 & 10 & - & - \\
\hline Average price (rand) & 2,854 & 350 & 260 & 285 & 350 & 250 & - & - \\
\hline \multicolumn{9}{|l|}{ Revenue sources(\% of total revenue) } \\
\hline Tourism accommodation & 95 & 2 & 79 & 95 & 0 & 5 & 0 & 0 \\
\hline Biltong hunting & 0 & 0 & 0 & 0 & 0 & 17 & 1 & 0 \\
\hline Cattle & 0 & 0 & 0 & 0 & 0 & 0 & 84 & 0 \\
\hline Game meat & 0 & 0 & 0 & 0 & 0 & 1 & 0 & 0 \\
\hline Live game sales & 0 & 92 & 2 & 0 & 100 & 71 & 14 & 100 \\
\hline Retail & 6 & 0 & 3 & 2 & 0 & 0 & 0 & 0 \\
\hline Trophy hunting & 0 & 6 & 16 & 0 & 0 & 6 & 2 & 0 \\
\hline \multicolumn{9}{|l|}{ Labour } \\
\hline Number of workers & 194 & 84 & 20 & 19 & 9 & 10 & 75 & 10 \\
\hline Labour cost (rand/ha) & 2,788 & 600 & 664 & 471 & 238 & 87 & 233 & 14 \\
\hline Labour cost (\% of total expenditure) & 77 & 21 & 43 & 63 & 51 & 18 & 19 & 18 \\
\hline \multicolumn{9}{|l|}{ Financial and economic results } \\
\hline Gross income (rand/ha) & 8,706 & 4,936 & 2,231 & 105 & 1,643 & 1,099 & 2,906 & 150 \\
\hline Gross margin (rand/ha) & 8,282 & 2,886 & 856 & 4 & 1,434 & 768 & 1,947 & 90 \\
\hline Private cost ratio & 0.38 & 0.44 & 0.13 & -1.51 & 0.34 & 0.69 & 0.16 & 0.16 \\
\hline Domestic resource cost & 0.2 & 0.22 & 0.59 & -1 & 0.26 & 0.43 & 0.11 & 0.08 \\
\hline Effective protection coefficient & 0.94 & 0.88 & 0.92 & 0.94 & 0.96 & 1.03 & 0.91 & 0.9 \\
\hline Profitability coefficient & 0.73 & 0.64 & 0.14 & 1.18 & 0.86 & 0.55 & 0.86 & 0.83 \\
\hline Net policy transfer (\% tax on net profits) & 27 & 36 & 86 & -18 & 14 & 45 & 14 & 17 \\
\hline
\end{tabular}

PAM, Policy Analysis Matrix; N/a.

the South African economy from both a private and social perspective. In terms of the prices that guide the farmer to make land use decisions, the private value-added exceeds costs of domestic factor inputs. Said technically, the private cost ratio shows that, for each rand of net profit (A-B), 38cents goes to pay domestic factors (C). This leaves a net profit of 62 cents which is substantial (i.e., $\mathrm{PCO}=\mathrm{C} /(\mathrm{A}-\mathrm{B})=0.38$ ). When prices are adjusted to correct pricing distortions, wildlife generates one rand of profit from 20 cents of domestic factors costs (i.e., Domestic Resource Cost Ratio (DRC) = $\mathrm{G} /(\mathrm{E}-\mathrm{F})=0.196)$. Economically speaking, wildlife has a comparative advantage and is a good use of drylands in South Africa.

We can now use the PAM to advise policy makers as to how market failures are effectively taxing or subsidising wildlife. First, we assess the impacts of exchange rate and trade policies using the Effective Protection Coefficient (EPC). On Farm (a), the social value-added (E-F) exceeds the private value-added (A-B) by only 6\% (i.e., EPC $=(A-B) /$ $(E-F)=0.94)$, which confirms that product markets in South Africa are relatively free and only slightly disadvantaging wildlife. Second, we use the profitability coefficient to 
measure the overall effect of all policy distortions on the enterprise. On Farm (a), this is $\mathrm{D} / \mathrm{H}=0.73$, so overall, Farm (a)'s private profit is $27 \%$ lower than it would be in the absence of economic distortion. This suggests that, in South Africa, domestic factors (i.e., immovable land, labour, and capital) are moderately distorted and that, if we corrected these issues, wildlife would be $27 \%$ more profitable.

There is considerable variability amongst the eight properties, depending upon the specific configuration of their enterprise and cost structures. Nonetheless, wildlife clearly provides significant jobs from marginal land. It is an economically efficient use of drylands in South Africa (DRC $<1$ ). It is also profitable to farmers despite government policies being disadvantageous to wildlife. However, Musengezi's research also showed that game ranchers faced significantly more nonfinancial barriers compared to conventional agricultural enterprises in the form of additional regulations and permissions. Her analysis is a single snapshot in time and does not incorporate habitat recovery or the considerable increases in land values associated with wildlife properties.

\section{Conceptualizing wildlife as an economic option}

We can use two conceptual diagrams to summarize the economics of wildlife. Figure 7 hypothesizes that wildlife outcompetes livestock agriculture in some drylands because it is easily diversified through hunting and tourism. These advantages are magnified at the economic or societal level because the wildlife sector is associated with vertical integration (lodging, guiding, etc.) and tourism multipliers (e.g., backwards linkages to inputs like food, wine, transport, etc.) that are far higher than for simple commodities (like meat).

This has important policy implications. In terms of development, wildlife utilization is a sensible land use option judged purely in terms of jobs and economic growth in some drylands (Figure 8). Therefore, policies that internalize both the costs and benefits of wildlife are likely to result in positive conservation and development outcomes. Conservationists also need to take this seriously, recognizing that national parks in many savannas can

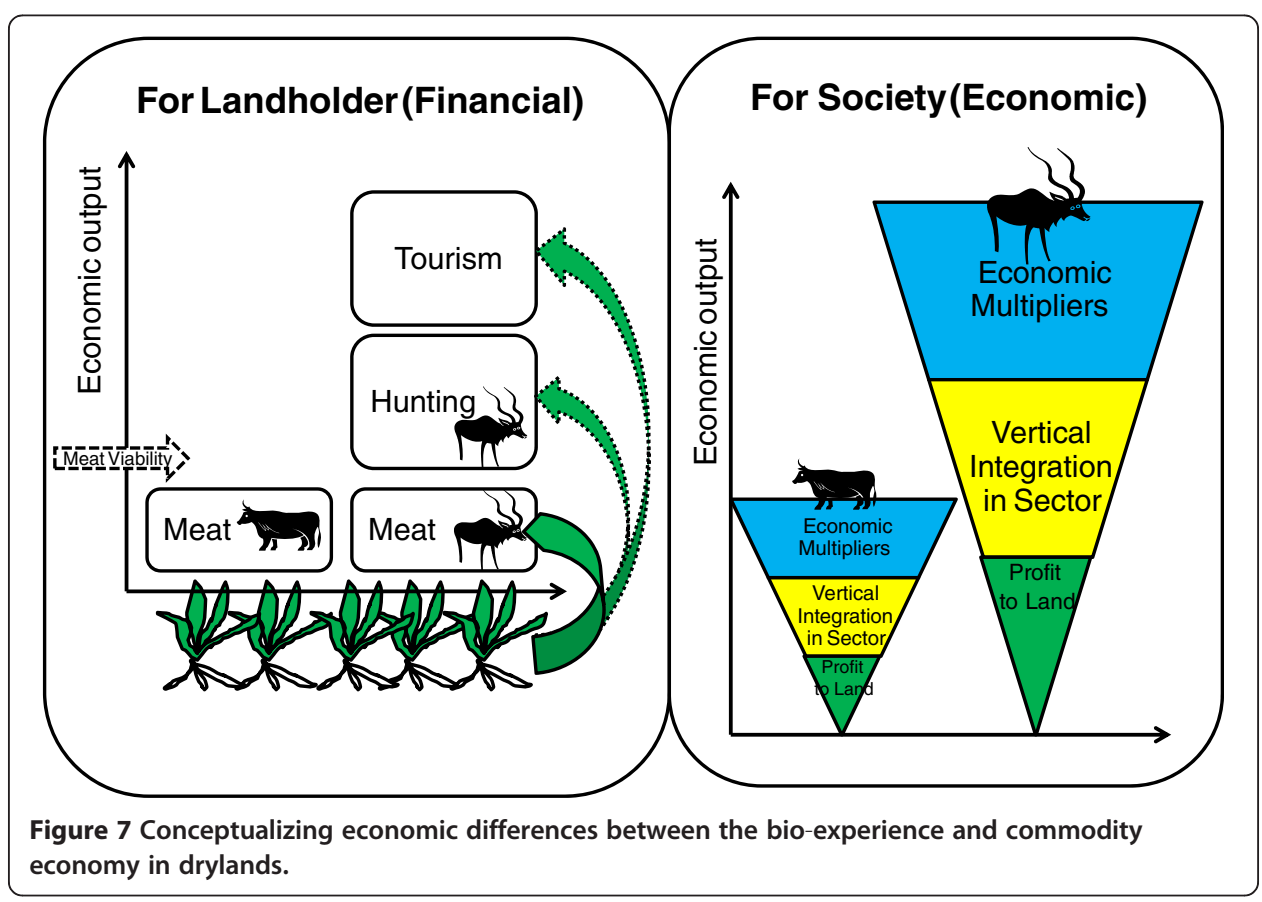


achieve their conservation objectives while also functioning as engines for economic growth and rural development, which is also an important social responsibility.

In higher-rainfall agricultural areas, the argument is reversed (Figure 8). If we want to conserve representative samples of these environments, we will need to subsidize them (e.g., protected areas) because wildlife is only economically competitive on patches of land that are difficult to farm (e.g. wetlands and hills) or uniquely accessible to markets in cities.

Figure 8 also illustrates a critical difference between agriculture and natural resourcebased systems. In traditional agricultural zones, ecosystems are greatly simplified, and environmental energy is channeled directly into one, or at most a few, products like cotton or corn. Outside these zones, people tend to harvest plants indirectly using animals (e.g., drylands) or to harvest a much wider variety of plant and animal products (e.g., tropical forests). In drylands, humans harvest the third trophic tier. There is a quantum loss in productivity because energy is lost in transfers between trophic layers, and commodity production is ecologically limited (illustrated in Figure 8). It is in these three-tier environments that the bio-experience economy has a comparative economic advantage over agro-extractive commodity production. However, historically, the wildlife in these ecosystems was undervalued and replaced by livestock. Policy and market failures, especially the nationalization of wildlife, restrictions to commercial use, and subsidization of commodity sectors, sent out the wrong pricing signal to landholders. This trend was only reversed when radical changes in wildlife policy began to address market failures by (a) devolving use rights for wildlife to landholders and (b) encouraging commercial use. Where market failures remain pervasive, for example where wildlife remains nationalized (e.g., Kenya), and in communal lands where access to resources remains open, wildlife continues to be replaced (see below).

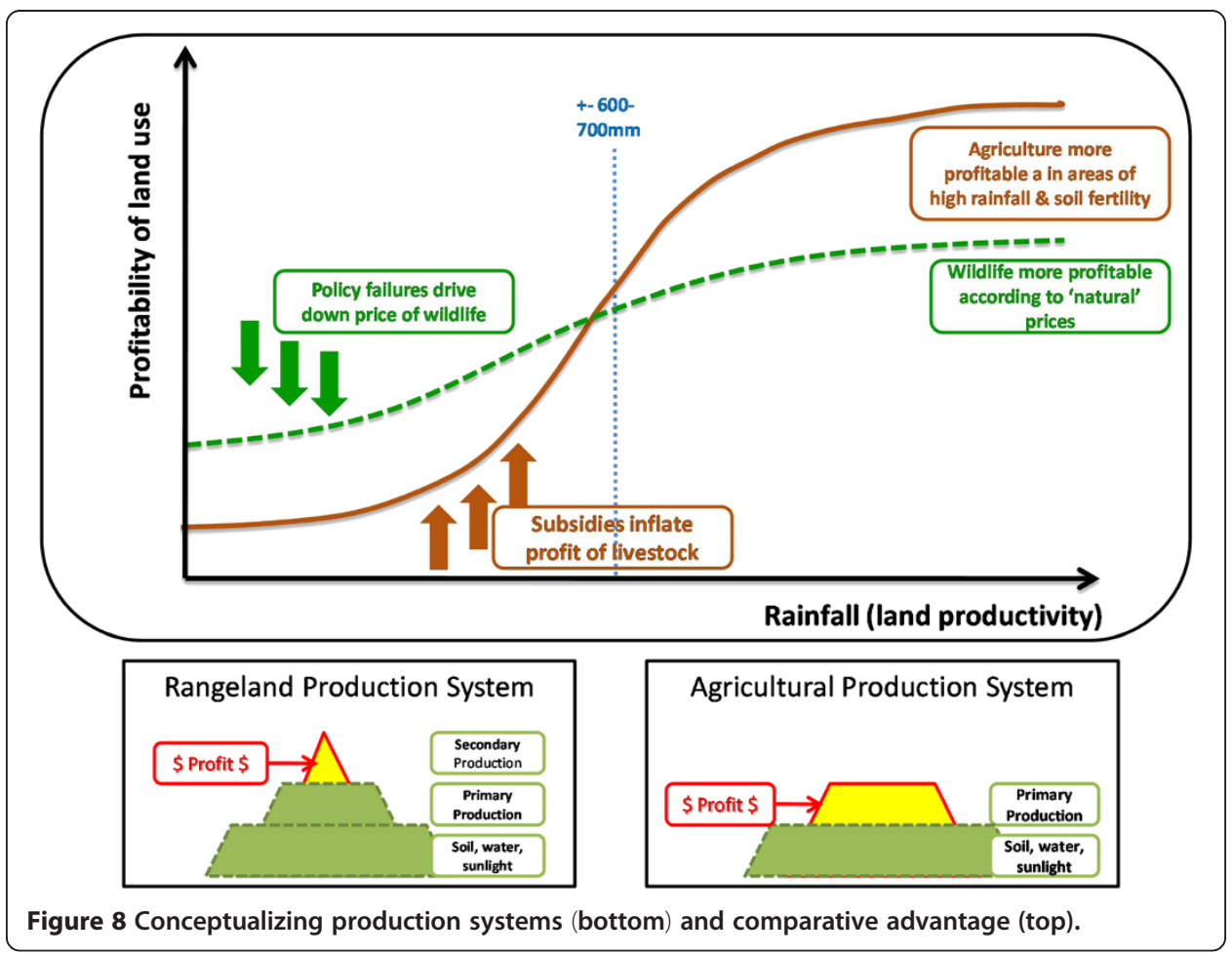




\section{Institutions and value}

Walker et al. (2004) use the example of private conservation in southern Africa to illustrate how complex systems flip from one zone of attraction to another. Under early colonial policies, ranches in southern African was locked in a mutually reinforcing cycle of environmental degradation and financial crisis associated with beef commodity production, but when these policies were changed, landholders quickly adapted, giving rise to a dynamic and profitable wildlife sector. That the natural environment is the same but that radical change followed a change in the rules, alerts us to the importance of these rules and introduces the field of institutional economics (North 1990). Institutions are the rules and norms that guide human behaviour, including the allocation of resources. Institutions like property rights and markets allow wealth to be created through processes of specialization, diversification, and exchange, so institutionally rich countries are usually wealthier than institutionally poor ones (North 1995). We hypothesize that this same logic applies to drylands: institutionally rich drylands produce much greater value than those that are institutionally thin because richer institutions enable landholders to convert ecological raw materials into higher-order goods and services without damaging the resource base. Thus, new institutions like wildlife property rights, tourism markets, banks, wildlife auctions, etc. have added considerable value to wildlife through processes of specialization, diversification, economies of scale, investment, and exchange. New wildlife institutions add value, allowing land to generate upward from South African Rand $\mathrm{R} 1,000 /$ ha, and some R100/ha, to R2,788/ha in wages alone (Table 6). Moreover, the devolution of wildlife rights to 10,000 private landholders has fueled considerable innovation in the development of wildlife products, which has driven up the value of wildlife in ways that have not happened when natural resources are monopolized by the state. Thus, southern Africa provides a multitude of hunting and tourism experiences from walking with lions to having moonlit dinners in the bush, whereas in Kenya and Tanzania, most tourists are restricted to closed vehicles in state-managed wildlife areas. We can use the price of South Africa's relatively unspectacular wildlife as a benchmark of its potential value. This suggests that the value of wildlife is far lower than it should be in centralized and institutionally thin wildlife sectors, including many communal lands.

Our discussion of the relationship between the institutional richness and economic productivity of drylands reflects Douglass North's explanation for why some countries are rich and others poor. North postulates that the most dramatic shift in human history has been from a personalized economy of big men and small-scale economic and political activity to an impersonal economy that relies on rules that allow us to transact reliably all over the world and with people we don't know, allowing humans to specialize and diversify on much higher scales than ever before (North 2003).

In Zimbabwe, enriching wildlife institutions by devolving proprietorship to landholders, encouraging trade, and establishing institutions like producer associations and auctions (Child 1995) created value by converting raw materials into higher-value goods and services by replacing low-value meat production (i.e., beef or bushmeat) with high-value ecotourism. However, these gains rely on institutions, and when the rule of law breaks down (degrading institutions such as property rights, courts, arbitration, and economic exchange), people can no longer rely on impersonal institutions (North 2003). Personalized Big-Man economies re-exert themselves (Beinhocker 2006), and institutional breakdown often benefit elites (Chabal and Daloz 1999). The renewable 
resource economy, especially sectors like wildlife that rely on economies of scale and exchange, is quickly disrupted, and land use reverts to resources that people can own and protect individually like livestock or crops.

Similarly, communal lands are institutionally thin, lacking title deeds and genuine proprietary rights to wildlife and other natural resources like carbon. This locks in a reliance on privately owned livestock and individual (but untitled) fields even when these are low-value land use options. We can develop a rough estimate of the opportunity costs of weak institutions by comparing the output of communal and private drylands (400 to $600 \mathrm{~mm}$ annual rainfall) outside Kruger National Park, using data from Gregory Parent and Jessica Musengezi. In 2010, Parent conducted comprehensive surveys of production and consumption data from households in the Mutale area bordering northern Kruger National Park, in a study looking at the impacts of market access on household vulnerability and resource use decisions (unpublished data). His data show that conventional livestock and farming adds little or no value in terms of cash income or jobs (Table 7). The net output of South African Rand R232/ha from the local area is less than half of the requirements needed to maintain household consumption at R532/ ha (Table 8). People are highly dependent on transfer payments from family members with jobs in urban areas and mines, and from government grants. Nonetheless, cropping, natural resource collection, and livestock are important risk mitigation and coping strategies, especially for poorer households. Households tend to view cattle more as an insurance policy than as a production commodity because they have limited access to formal insurance institutions.

The key point is that, in the same agro-economic region, there is a 10 to 40 times difference in economic output between institutionally rich private land and institutionally thin communal land (noting also that communal lands suffer enormously from the legacies of apartheid). Communal lands also suffer disproportionately from overgrazing in a tragedy-of-the-commons-type situation where environmental costs are externalized to society (Hardin 1971). Our suggestion is that the opportunity costs of weak institutions are enormous, and the return on investment from developing new institutions may be high.

\section{Policy 'failure' in East Africa}

The economic value of institutions is highlighted by the case of wildlife in East Africa. East Africa's wildlife is inherently superior to southern Africa, and the hunting sector only moved southwards when it was restricted in East Africa in the early 1970s. In contrast to southern Africa, postcolonial East Africa perpetuated colonial policies of state nationalisation, monopolisation, and centralization of wildlife (Kabiri 2010). Several private landholders such as David Hopcraft in Kenya have struggled to develop wildlife as

Table 7 Annual output from land use activities in Benda Mutali communal area ${ }^{\mathrm{i}}$

\begin{tabular}{lccc}
\hline \multicolumn{1}{c}{ Activity } & Total output & Output per hectare & Output per household \\
\hline Crops & 97,185 & 4.19 & 171 \\
Livestock & $1,737,474$ & 74.89 & 3,048 \\
Natural resources & $2,537,184$ & 109.36 & 4,451 \\
Labor & $1,017,279$ & 43.85 & 1,785 \\
Total & $5,389,122$ & 232.29 & 9,455 \\
\hline
\end{tabular}

'All values in South African Rand (US dollar $\$ 1=\mathrm{R} 7$ '.

ii Area based on mapping exercise with community to calculate spatial extent of production, estimated to be 23,200 ha. 
Table 8 Annual household consumption in Benda Mutali

\begin{tabular}{lccc}
\hline \multicolumn{1}{c}{ Activity } & $\begin{array}{c}\text { Total household } \\
\text { consumption }\end{array}$ & $\begin{array}{c}\text { Consumption per hectare } \\
\text { ii }\end{array}$ & $\begin{array}{c}\text { Consumption per } \\
\text { household }\end{array}$ \\
\hline Crops & 97,185 & 4.19 & 171 \\
Livestock & 768,152 & 33.11 & 1,348 \\
Natural resources & $1,364,392$ & 58.81 & 2,394 \\
Food purchases & $5,242,040$ & 225.95 & 9,197 \\
Non-food & $4,207,784$ & 181.37 & 7,382 \\
purchases & & & \\
Asset depreciation & 718,040 & 30.95 & 1,260 \\
Total & $12,397,593$ & 534.38 & 21,750 \\
\hline
\end{tabular}

All data in South African rand. (US dollar $\$ 1=\mathrm{R} 7$ ).

ii Area based on mapping exercises with community to calculate spatial extent of production.

a land use option for many years but suffer from weak proprietary rights, bureaucratic uncertainty, and restrictions on use. Thus, Hopcraft relies on tourism and the sale of meat to Nairobi for his income rather than on the potentially more lucrative safari hunting, which is banned in Kenya (personal communication). Some large landholders manage wildlife for tourism, but it would be a more competitive land use option in, for instance, the Laikipia district if hunting was legalized (Craig, personal communication). In Tanzania, hunting is legal, but the proceeds from hunting are seldom returned to landholder communities, while the state is also extracting most tourism revenues from community areas (Nelson 2010). Wildlife in prime areas in Kenya (e.g., Mara) has declined to a third or less of its former (1977) abundance (Ogutu et al. 2011), and there may well be similar downward trends in Tanzania, but data is sparse and often restricted.

\section{Externalities, collective action, and scale}

Wildlife is a mobile resource that, like many natural resources, is associated with externalities, for example, where one landholder conserves a species only for his neighbour to hunt them or where wildlife damages crops on a neighbouring property. These externalities are the reason why individual ownership of wildlife is thought to be problematic and has been centralized in the state. However, externalities may be easier to solve in practice than theoretical approaches might suggest. This requires cross-scale institutions. Following the principle of subsidiarity, these need to be built up from the bottom. The primary goal is to internalize the costs and benefits of wildlife management at the level of landholders because they are deterministic of land use outcomes. The first essential step is to devolve proprietorship to landholders. Second, mechanisms are needed to manage externalities associated with the fugitive character of wildlife and other natural resources.

South Africa and Namibia manage wildlife's externalities with physical infrastructure. The right to utilize wildlife is linked to a 'certificate of adequate enclosure' and requires that wildlife properties are appropriately fenced. Game fencing solves problems associated with wildlife's mobility but introduces new problems because game fences are expensive and fragment landscapes. The sedentarisation of wildlife on small, fenced private ranches negates many natural behavioural advantages, allows overstocking, and results in the negative impacts on environments associated with decreased mobility in 
ruminants. Mismanagement of any animals, domestic or wild, causes ecological problems, and fencing savannas is a form of mismanagement. In the early days of game farming in South Africa, overstocking was a considerable concern, though the situation is improving with management experience and mechanisms for scaling up, such as conservancies.

The alternative to managing externalities with physical infrastructure is to manage them with institutions, as was done in Zimbabwe. Zimbabwe's far-sighted Natural Resources Act of 1941 enabled farmers to voluntarily establish themselves (usually 30 to 50 landholders in a catchment) as democratically-managed Intensive Conservation Areas (ICA) with more power to regulate themselves than anything a centralized state would dare to impose. ICAs had the power to require members to address soil erosion at their own financial cost, reduce livestock where overstocking was degrading the grass layer, desist from tree cutting, or set quotas and other restrictions on the use of wildlife species. Communities designed locally appropriate rules, which were enforced through peer pressure backed by the possibility of legal action. In essence, the community became the primary locus of regulation and enforcement. The state retained responsibility for regularly inspecting land to ensure that ICAs were performing and could intervene if this community-based system failed, but this was rarely required. The Act also established a court to which landholders could appeal.

ICAs became the focal point for social learning, collective action, and peer control of wildlife management, as farmers met to regulate and learn from each other. Selfregulation was parsimonious but effective. Landholders were financially and socially accountable for regulations they custom designed for their particular circumstances. They limited regulation to high-value species and circumstances with real benefits from regulation, and where regulations were socially acceptable and could be enforced. For example, in the Munyati-Sebakwe ICA, farmers set quotas for high-value species like sable and waterbuck that were still building up after the livestock era but did not waste their time regulating ubiquitous or territorial animals like impala and kudu. In the severe 1984 drought, the Chiredzi ICA acted collectively to save the few remaining sable in the area by capturing and feeding them (sable having been severely threatened by livestock overgrazing). As the species recovered, they judiciously increased hunting quotas, rewarding ranchers who successfully recovered their sable populations with higher quotas. In another example, one landholder was luring wildlife onto his land using fire and fodder to capture and sell them, but the ICA resolved this problem by imposing quotas on him. These issues were usually solved informally through peer pressure backed up by the ICA's power to impose collective solutions if they needed to. The system was inexpensive and highly effective. Decisions and enforcement were internally legitimated, managed primarily through peer pressure, and tightly designed to suit local circumstances.

The ICA system not only used social interaction to manage the externalities associated with natural resources but also provided a grassroots democratic system by which government officials were held accountable for natural resource policies. ICAs had direct statutory access to key ministers, parliament, and even the prime minister, and it is no coincidence that the movement was strongly supported by research, extension, and even environmental education both in schools and for adults (Child and Child, in preparation). Theoretically speaking, Zimbabwe's natural resource legislation 
combined privatization of wildlife to internalize costs and benefits at the level of the individual property, with collective action to control the spatial and temporal externalities associated with wildlife and natural resources.

\section{Private conservancies}

In the 1990s, many ranchers began to recognize ecologies and economies of scale. They formed conservancies, whereby up to 30 ranchers agree, often contractually, to manage their wildlife collectively. This allowed a second economic transition. Whereas individual game ranchers could reintroduce rarer species like sable, hartebeest, and rhino, large wildlife collectives could restock big game like elephant, buffalo, lions, and even wild dogs. For example, the Save Conservancy in southeastern Zimbabwe captured over 600 elephants in the drought-stricken Gona-re-zhou National Park and restocked lions, wild dogs, buffalos, and plains game. In South Africa, landholder collectives removed the fence between themselves and Kruger National Park and generate substantial revenues from hunting and tourism. The economies of scale associated with tourism and wildlife allowed these huge private reserves to share management costs and principles over a larger area and to generate more money than individual properties.

\section{Community-based natural resource management (CBNRM)}

From the early 1970s, conservation bureaucrats in Zimbabwe, Namibia, and Botswana (and also Zambia) argued that it was unfair that only white farmers should benefit from wildlife and that, if similar rights were devolved to communal areas, both rural people and wildlife would benefit (Metcalfe 1993). This led to the emergence of community-based natural resource management (CBNRM) in southern Africa where, led by Zimbabwe's iconic CAMPFIRE programme (Child 1993; Murphree 2005; Frost and Bond 2008; Taylor 2009), hunting and tourism revenues were returned to communities. From a conservation perspective, this stabilised or even increased wildlife populations in Zimbabwe's crowded communal lands (Child et al. 2003), and the recovery of wildlife, including endangered rhinos and elephants, was even stronger in Namibia (NACSO 2008). Income from wildlife contributed to social projects, provided cash to households in some projects (Dalal-Clayton and Child 2003; Jones and Weaver 2009), and helped to empower local people (Jones and Murphree 2004). In some communities, employment and income from hunting and tourism contributed significantly to livelihoods, providing as much as three-quarters of on-farm livelihoods to the Sankuyo community in Botswana (unpublished data).

Community-based natural resource management (CBNRM) is the subject of a considerable literature, and we emphasize only key issues here. First, wildlife-based CBNRM is founded on the potential to use wildlife as an economic engine in communal lands and, in so doing, to incentivise conservation. Second, CBNRM mostly does not involve a trade-off between conservation and development because it is an institutional approach that allocates natural resources including wildlife to higher valued uses, and in some cases, more equitably. Thus, CBNRM can and should simultaneously contribute to both conservation and development, as happened for private land. Third, CBNRM relies on two sets of institutions: those that devolve rights (or not) from state and community and about which much is written (Murphree 2004; Nelson 2010), and those within a community that promote participation and equitable benefit sharing, which is an emerging challenge that has hardly been studied.

As with private conservation, an essential ingredient of CBNRM is the devolution of the rights and benefits for wildlife to communities. Where all (e.g., Botswana and Namibia) or 
most (e.g., Zimbabwe) income has been devolved to communities, CBNRM has encouraged the recovery of wildlife and generated significant incomes (NACSO 2008; Taylor 2009), but has not magically (and unrealistically) resolved poverty, because of the number of people involved and because wildlife populations are still low and recovering in hot, dry, and remote environments. CBNRM is also difficult to implement when human densities are high, wildlife populations are depleted, and benefits are low. However, the so-called 'crisis' in CBNRM reflects a failure of implementation and, specifically, a failure to devolve rights and responsibilities to communities within a carefully designed institutional framework. Many, if not most CBNRM programmes, do not represent a serious attempt to devolve revenues to communities and therefore cannot be expected to work (Nelson 2010; Ribot 2003). These are CBNRM programmes in name only, and wildlife is neither benefiting communities nor recovering therefore.

The emerging challenge for CBNRM, and about which little is written, is the challenge of within-community governance. Commonly CBNRM programmes generate revenue and recover wildlife populations, but like many decentralization projects, they are plagued by elite capture, misuse of money, and low levels of participation. In our experience, this is because they rely on representational forms of governance whereby leaders elected by a community sit on committees that make many or most of the decisions on behalf of the community. The assumption is flawed that bi- or tri-annual elections and annual general meetings will achieve accountability, participation, transparency, and equitable benefit sharing (and guard against financial misappropriation and elite capture).

Challenging as it may seem, participatory democracy may be an essential starting point and building-block for a successful CBNRM (and much easier to implement than first assumed). Real participation requires that CBNRM communities are defined at a scale and implement participatory processes that allow the majority of the people to (1) meet face-toface to share information and make decisions, (2) instruct the committee to implement these decisions, and (3) review the quality of implementation (i.e., does expenditure reflect the budget agreed upon by the community?) no less than quarterly.

\section{Scaling up and scaling down at the same time}

The experience of private game ranching demonstrates that wildlife can greatly increase the economic output from drylands. We can have confidence in wildlife utilization as an economic model. However, we need to develop new governance models to substantially increase levels of participation and benefit sharing, and that prevent money from being diverted to administrative expenses and elite capture. We suggest that this requires CBNRM programs to be scaled down to the level of single-village communities and processes of participatory democracy be strictly followed. In other words, CBNRM requires carefully crafted institutions to manage the challenge of scale. These institutions need to scale up for reasons of ecological and economic scale, but also to simultaneously scale down to improve accountability, participation, and equitable benefit sharing (Child, unpublished data).

\section{Hunting}

One of the more controversial and misunderstood aspects of wildlife utilization is hunting. Trophy hunting is an ecologically robust and high-value use of wildlife. It is true that non-hunting tourism can outcompete hunting tourism economically but only in prime areas with excellent wildlife. Hunting remains the bread and butter of wildlife 
operations, especially in non-prime areas and in times of global or national crisis when tourists stop traveling but hunters do not. Hunting provides a significant cash flow from very few animals, facilitating the transition towards wildlife-based land uses. Indeed, it is difficult to make the transition from livestock to wildlife in the absence of hunting, except for people with large amounts of money to invest. We see this even in the development of Pilanesberg Game Reserve in South Africa (Johnson et al. 2009). The government purchased degraded livestock ranches to form a new park on the basis that this was a better economic use of the land. The transition was partly financed by carefully controlled trophy hunting of excess males. Hunting was carefully zoned in time and place to avoid conflicts with the rapidly growing photo-safari business while careful hunting practices were used, so wildlife did not associate gunshots with vehicles or people.

Hunting is an essential component of the transition to wildlife-based land uses. However, as wildlife populations and diversity recover, landholders are able to introduce photographic tourism, building attractive lodges, and training significant numbers of local guides, cooks, caterers, and managers. However, even in these circumstances, photo-tourism and hunting are compatible. Conflicts are certainly common between tour operators and hunting outfitters when they are competing for land and wildlife (e.g., around the Okavango Delta in Botswana and the Luangwa Valley in Zambia), but such problems seldom arise when the same manager is responsible for both operations, as in the Pilanesberg example.

\section{Conclusions}

It has taken 60 years for wildlife to emerge as an important and economically viable land use option. It is now a proven economic model, and given the right ecological and institution circumstance, wildlife can provide significantly more jobs and economic growth than conventional uses of the same land. We still face the challenge of how to apply this model more broadly in Africa's communal lands, a challenge that requires genuine devolution of proprietorship from government to community and democratic and effective organizational development within communities.

The wildlife option has emerged through proactive policy making and private sector entrepreneurship. Far-sighted conservation bureaucrats challenged the postcolonial status quo and developed a new approach to wildlife conservation based on landholder benefit. They sought to maximize the value from wildlife to people living with it by (1) devolving full proprietorship to landholders, (2) encouraging sustainable commercial uses provided they were humane, and (3) reducing the regulatory burden on the sector. This allowed thousands of wildlife owners to experiment with new products, steadily driving up the value of wildlife in ways that we seldom see with other wild resources like forests. Where institutions were changed in this way, mainly on private land but also in some communal lands, wildlife and the habitats on which it depends have recovered enormously. But where wildlife remained centralized and noncommercial, wildlife populations have declined.

Many drylands are locked in a reinforcing cycle of ecological over-utilization, but economic under-utilization often linked to a reliance on commodity-based production systems. Bold policy facilitated a transformation to an economy based not on commodities but on experiences - the wildlife and bio-experience sector. This generates more economic activity yet extracts far less from the environment and, though it seems 
counterintuitive in a world afflicted with poverty, the terms of trade for tourism and experiences are improving steadily whereas the price of agricultural commodities has been stagnant or falling for several decades.

In the past few years, recognition of the importance of ecosystem services has increased. In the most thorough analysis to date, Robert Constanza and his colleagues demonstrated that the value of ecosystems exceeds global GDP by several factors (Costanza, d'Arge et al. 1997). But the problem is that these values are not reflected in the private prices that guide the decision makers of landholders nor, therefore, in land use outcomes. In the 1960s, wildlife faced these very same problems. They were addressed by adopting a new approach to conservation based on well-crafted institutions at both the national and local level that sought, first, to maximize the value of wildlife to the landholder by internalizing (privatizing) its benefits and costs at the level of the landholder, and to simultaneously establish democratic collective action to manage externalities and scale. Contrary to the predictions of conservationists, commercializing wildlife in this way has had positive conservation and development outcomes. Positive outcomes hinge on the simultaneous application of two factors: driving up the price of wildlife (i.e., price) while ensuring that benefits and management are controlled by landholders (i.e., proprietorship and subsidiarity). In the absence of proprietorship, for example, the high price of ivory and rhino horn has been disastrous, but taking away the value of wildlife is not a solution either because it is quickly replaced by alternative land uses.

The development of the wildlife sector has been a policy experiment based on the hypothesis that giving wildlife value to the people who live with it will result in positive development and conservation outcomes, requiring considerable tenacity and adaptive learning in navigating towards this objective in complex economic and political circumstances. The approach has succeeded where laws, regulations, and operational procedures have incorporated the principles of price, proprietorship, subsidiarity, and adaptive management in a theoretically sound and disciplined manner. Indeed, wildlife provides a pioneering example of Payments for Ecosystem Services, which was relatively easy to implement because of the high value of wildlife and the relative simplicity of costs and benefits attribution (at least compared to ecosystem processes). Ecosystem services are facing similar market failures of wildlife. The challenge of our generation may well be to convert these values into incentives for maintaining ecosystem services, perhaps by adapting some of the lessons from the wildlife sector in southern Africa.

Competing interests

The authors declare they have no competing interests.

Authors' contributions

BC conceptualized and compiled the paper. JM provided data on game ranching and GP provided data on community livelihoods in South Africa. GC strengthened the paper's historical and policy perspectives. All authors read and approved the final manuscript.

Author details

${ }^{1}$ Stellenbosch Institute for Advanced Studies (STIAS), Wallenberg Research Centre at Stellenbosch University, Marais Street, Stellenbosch 7600, South Africa. ²Department of Geography, Center for Africa Studies, University of Florida, 427 Grinter Hall, P.O. Box 115560, Florida, USA.

Received: 19 October 2011 Accepted: 5 March 2012

Published: 28 September 2012

References

Astle, WL. 1999. A History of wildlife conservation and management in the mid-Luangwa Valley, Zambia. Bristol: British Empire and Commonwealth Museum. 
Barnes, J, and B Jones. 2009. Game ranching in Namibia. In Evolution and innovation in wildlife conservation, ed. H. Suich and B. Child, 113-126. London: Earthscan.

Beinhocker, ED. 2006. The origin of wealth: evolution, complexity and the radical remaking of economics. Boston: Harvard Business School Press.

Bell, RHV. 1982. The effect of soil nutrient availability on community structure in Africa savannas. In Ecology of tropical savannas, ed. BJ Huntley and BH Walker, 193-216. Berlin: Springer verlag.

Booth, V. 2002. Analysis of wildlife markets (sport hunting and tourism). Harare: WWF Southern African Regional Programme Office.

Booth, VR. 2009. A comparison of the prices of hunting tourism in southern and eastern Africa. Budapest: Joint publication of Food and Agriculture Organization of the United Nations (FAO) and International Council for Game and Wildlife Conservation (CIC).

Borgerhoff Mulder, M, and P Coppolillo. 2005. Conservation: linking ecology, economics, and culture. Princeton: Princeton University Press.

Bothma, Jd P, H Suich, and A Spenceley. 2009. Extensive wildlife production on private land in South Africa. In Evolution \& innovation in wildlife conservation, ed. H Suich and B Child, 147-162. London: Earthscan.

Brockington, D, and J Igoe. 2006. Eviction for conservation: a global overview. Conservation and Society 4(3): 424-470.

Campbell, A, and G Child. 1971. The impact of man on the environment of Botswana. Botswana Notes and Records 3 : $91-110$.

Carruthers, J. 1989. Creating a national park 1910-1926. Journal of Southern African Studies 15: 188-216.

Carruthers, J. 2008. "Wilding the farm or farming the wild"? The evolution of scientific game ranching in South Africa from the 1960s to the present. Transactions of the Royal Society of South Africa 63(2): 160-181.

Chabal, P, and JP Daloz. 1999. Africa works: the political instrumentalization of disorder. Oxford: James Currey.

Chadwick, DH. 1996. A place for parks in the new South Africa. National Geographic 190(1): 2-41.

Child, G. 1971. The future of wildlife and rural land use in Botswana. Proceedings of the SARCCUS Symposium. Gorongoza National Park, Mozambique: Nature Conservation as a Form of Land Use.

Child, B. 1988. The role of wildlife utilization in the sustainable economic development of semi-arid rangelands in Zimbabwe. PhD thesis: University of Oxford.

Child, B. 1993. Zimbabwe's CAMPFIRE programme: using the high value of wildlife recreation to revolutionize natural resource management in communal areas. Commonwealth Forestry Review 72(4): 284-296.

Child, G. 1995. Wildlife and people: the Zimbabwean success. How the conflict between animals and people became progress for both. Harare: Wisdom Foundation.

Child, B. 2004a. The Luangwa integrated rural development project, Zambia. In Rights, resources and rural development. Community-based natural resource management in Southern Africa, ed. C Fabricius, E Kock, H Magome, and S Turner, 235-247. London: Earthscan.

Child, B. 2004b. In, ed. B Child and MW Lyman, 17-50 Madison: Sand County Foundation and Washington: The Aspen Institute.

Child, B. 2006. Revenue distribution for empowerment and democratization. In Participatory Learning and Action 55: 2029.

Child, B. 2009. Game ranching in Zimbabwe. In Evolution and innovation in wildlife conservation, ed. H Suich and B Child, 127-146. London: Earthscan.

Child, B, and G Barnes. 2010. The conceptual evolution and practice of CBNRM in southern Africa - past, present and future. Environmental Conservation 37(3): 83-295.

Child, GFT, and T Riney. 1987. Tsetse control hunting in Zimbabwe, 1919-1958. Zambezia 14(1): 11-72.

Child, B, B Jones, D Mazambani, A Mlalazi, and H Moinuddin. 2003. Final evaluation report: Zimbabwe natural resources management program - USAID/Zimbabwe Strategic Objective No. 1. CAMPFIRE Communal Areas Management Programme for Indigenous Resources, 153. Washington: USAID.

Coe, MJ, DH Cumming, and J Phillipson. 1976. Biomass and production of large African herbivores in relation to rainfall and primary production. Oecologia 22: 341-354

Costanza, R, d' Arge R, R de Groot, S Farberk, M Grasso, Hannon Bruce, K Limburg, S Naeem, RV O'Neill, J Paruelo, RG Raskin, Suttonkk Paul, and M vanden Belt. 1997. The value of the world's ecosystem services and natural capital. Ecological Economics 25: 3-15.

Cousins, JA, JP Sadler, and J Evans. 2008. Exploring the role of private wildlife ranching as a conservation tool in South Africa: stakeholder perspectives. Ecology and Society 3(2):1-34. http://www.ecologyandsociety.org/vol13/iss2/art43/.

Cumming, DHM. 1982. The influence of large herbivores on savanna structure in Africa. In Ecology of tropical savannas, ed. BJ Huntley and BH Walker, 217-245. New York: Springer.

Cumming, D. 1995. Are multispecies systems a viable land use option for southern African rangelands? In Wild and domestic ruminants in extensive land use systems, ed. RR Hofmann and HJ Schartz, 203-234. Berlin: Humboldt University.

Cumming, DHM, and I Bond. 1991. Animal production in southern Africa: present practices and opportunities for peasant farmers in arid lands. Multispecies animal production systems project paper no. 22. Harare: WWF Multispecies Project.

Dalal-Clayton, B, and B Child. 2003. Lessons from Luangwa. The story of the Luangwa Integrated Resource Development Project, Zambia. London: International Institute for Environment and Development.

Dasmann, RF. 1964. African game ranching. Oxford: Pergamon Press.

Dasmann, RF, and AS Mossman. 1961. Commercial utilization of game animals on a Rhodesian ranch. Salisbury: National Museums.

Dry, G. 2010a. Why game farming should be taken seriously. South Africa: Farmer's Weekly, Pretoria. 14 May 2010.

Dry, GC. 2010b. Commercial wildlife ranching's contribution to the "green economy". South Africa: Green Economy Summit.

Frost, PGH, and I Bond. 2008. The CAMPFIRE programme in Zimbabwe: payments for wildlife services. Ecological Economics 65(1): 776-787. 
Grossman, D, and M Gandar. 1989. Land transformation in South African savanna regions. South African Geographical Journal 7(1): 38-45.

Hardin, GJ. 1971. The tragedy of the commons. Science 162: 1243-1248.

Heijnsbergen, VP. 1997. International legal protection of wild fauna and flora. Amsterdam: Landsdale IOS Press.

Hulme, D, and M Murphree. 2001. Community conservation in Africa. An introduction. In African wildlife and livelihoods The promise and performance of community conservation, ed. D Hulme and M Murphree, 1-37. Oxford: James Currey.

IUCN. 1963. Conservation of nature and natural resources in modern African states. IUCN Publications new series. Morges: International Union for the Conservation of Nature and Natural Resources.

Jansen, DJ, I. Bond, and B Child. 1992. Cattle, wildlife, both or neither? A survey of commercial ranches in the semi-arid regions of Zimbabwe. Harare: WWF Multispecies Animal Production Project, 203 plus appendices.

Jarman, PJ. 1973. The social organization of antelope in relation to their ecology. Behaviour 48(3/4): 215-267.

Jenkins, H. 2011. Opening address, 7th International Wildlife Ranching Symposium by Premier of the Northern Cape. Kimberly, South Africa: 7th International Wildlife Ranching Symposium.

Johnson, SR, W Boonzaaier, R Collinson, and R Davies. 2009. Changing institutions to respond to challenges: North West Parks, South Africa. In Evolution and innovation in wildlife conservation, ed. H Suich and B Child, 289-306. London: Earthscan.

Jones, BTB, and MW Murphree. 2004. Community-based natural resources management as a conservation mechanisam: lessons and directions. Parks in transition: biodiversity, rural development and the bottom line. In, ed. B Child, 63104 London: Earthscan.

Jones, B, and C Weaver. 2009. CBNRM in Namibia: growth, trends, lessons and constraints. In Evolution \& innovation in wildlife conservation, ed. H Suich and B Child, 223-242. London: Earthscan.

Kabiri, N. 2010. Historical and contemporary struggles for a local wildlife governance regime in Kenya. In Community rights, conservation \& contested land. The politics of natural resource governance in Africa, ed. F Nelson, 121-144. London: Earthscan.

Kelly, RD, and BH Walker. 1976. The effects of different forms of land use on the ecology of a semi-arid region in South-Eastern Rhodesia. Journal of Ecology 64(2): 553-576.

Langholz, JA, and GIH Kerley. 2006. Combining conservation and development on private lands: an assessment of ecotourism-based private game reserves in the Eastern Cape. Center for African Conservation Ecology: Nelson Mandela Metropolitan University. 31.

Libecap, GD. 2009. The tragedy of the commons: property rights and markets as solutions to resource and environmental problems. Australian Journal of Agricultural and Resource Economics 53(1): 129-144.

Lindsay, P, R Du Toit, A Pole, and S Romañach. 2009. Save Valley conservancy: a large scale African experiment in cooperative wildlife management. In Evolution \& innovation in wildlife conservation, ed. H Suich and B Child, 163-186. London: Earthscan.

Lindsey PA, GA Balme, et al. (2012). The Significance of African Lions for the Financial Viability of Trophy Hunting and the Maintenance of Wild Land. PLOS Biol 7(1).

Mahesh Sankaran, NPHRJS, J Ratnam, DJ Augustine, BS Cade, J Gignoux, SI Higgins, X Le Roux, F Ludwig, J Ardo, F Banyikwa, A Bronn, G Bucini, KK Caylor, MB Coughenour, A Diouf, W Ekaya, CJ Feral, EC February, PGH Frost, P Hiernaux, H Hrabar, KL Metzger, HHT Prins, S Ringrose, W Sea, J Tews, J Worden, and N Zambatis. 2005. Determinants of woody cover in African savannas. Nature 438: 846-849.

Martin, R. 1986. Communal areas management programme for indigenous resources. Revised edition. Harare: Department of Natural Parks and Wildlife Management, Branch of Terrestrial Ecology.

Martin, R. 2009. From sustainable use to sustainable development. Evolving concepts of natural resource management: IUCN - Southern African Sustainable Use Specialist Group 55.

Metcalfe, S. 1993. CAMPFIRE - Zimbabwe's communal areas management programme for indigenous resources. In Natural connections: perspectives in community-based conservation, ed. D Western, M Wright, and S Strum. Washington: Island Press.

Monke, EA, and SR Pearson. 1989. The policy analysis matrix for agricultural development. Ithaca: Cornell University Press.

Mossman, AS. 1975. International game ranching programs. Journal of Animal Science 40: 993-999.

Muir-Leresche, K, and RH Nelson. 2000. Private property rights to wildlife: the southern African experiment. Italy: International Centre for Economic Research.

Murphree, M. 1994. Communities as resource management institutions. London: International Institute for Environment and Development Gatekeeper Series. No 36.

Murphree, MW. 2004. Communal approaches to natural resource management in Africa: from whence to where? In Breslauer Symposium on Natural resource Issues in Africa. Berkeley: University of California.

Murphree, M. 2005. Congruent objectives, competing interests, and strategic compromise: concept and process in the evolution of Zimbabwe's CAMPFIRE, 1984-1996. Communities and conservation: histories and politics of community-based natural resource management. In, ed. JP Brosius, AL Tsing, and C Zerner, 105-148 Oxford: Rowman and Littlefield.

Musengezi, J. 2010. Wildlife utilization on private land: understanding the economics of game ranching in South Africa. PhD thesis: University of Florida.

NACSO. 2006. Namibia's communal conservancies. A review of progress and challenges in 2005. Windhoek: Namibian Association of CBNRM Support Organisations 104.

NACSO. 2008. Namibia's communal conservancies. A review of progress and challenges in 2007. Windhoek: Namibian Association of CBNRM Support Organizations 120.

Nelson, F. 2010. Introduction: the politics of natural resource governance in Africa. In Community rights, conservation and contested land: the politics of natural resource governance in Africa, ed. F Nelson, 3-31. London: Earthscan.

Nelson, F, and T Blomley. 2009. Peasants' forests and the king's game? Institutional divergence and convergence in Tanzania's forestry and wild life sectors. In Community rights, conservation and contested land: the politics of natural resource governance in Africa, ed. F Nelson. London: Earthscan.

North, DC. 1990. Institutions, institutional change and economic performance. Cambridge: Cambridge University Press. 
North, DC. 1995. The new institutional economics and third world development. In The new institutional economics and third world development, ed. J Harriss, J Hunter, and CM Lewis, 17-26. London: Routledge.

North, DC. 2003. Understanding the process of economic change. In Forum series on the role of institutions in promoting economic growth: June 24, 2003. Washington: Mercatus Center at George Mason University and The IRIS Center.

Ogutu, JO, N Owen-Smith, et al. (2011). Continuing wildlife population declines and range contraction in the Mara region of Kenya during 1977-2009. Journal of Zoology 283(2):99-109.

Parker, I. 2004. What I tell you three times is true: conservation, ivory, history and politics. UK: Librario.

Phimister, IR. 1978. Meat and monopolies: beef cattle in southern Rhodesia, 1890-1938. The Journal of African History 19: 391-414.

PriceWaterhouse. 1994. The Lowveld conservancies: new opportunities for production and sustainable land-use. Harare: Save, Bubiana and Chiridzi River Conservancies.

Ribot, JC. 2003. Democratic decentralisation of natural resources: institutional choice and discretionary power transfers in sub-Saharan Africa. Public Administration and Development 23(1): 53-65.

Ribot, JC, JF Lund, and T Treue. 2010. Democratic decentralization in sub-Saharan Africa: its contribution to forest management, livelihoods, and enfranchisement. Environmental Conservation 37(1): 35-44.

Riney, T. 1960. Rhodesian wildlife is a natural resource. Wild Life 2(1): 49-54.

Riney, T. 1963. A rapid field technique and its application in describing conservation status and trends in semi-arid pastoral areas. African Soils 8: 159-257.

Riney, T, and P Hill. 1967. Conservation and management of African wildlife. Rome: Food and Agriculture Organization FAO.

SASUSG. 1996. Sustainable use issues and principles.: Southern Africa Sustainable Use Specialist Group, IUCN Species Survival Commission 23.

Suich, H, and B Child (eds.). 2009. Evolution \& innovation in wildlife conservation. Parks and game ranches to transfrontier conservation areas. London: Earthscan.

Talbot, LM, HP Ledger, and WJA Payne. 1961. The possibility of using wild animals for animal production on East African rangelands based on a comparison of ecological requirements and efficiency of range utilization by domestic livestock and wild animals. In Reports of the 8th International Congress of Animal Production. Hamburg: Eugen Elmer Verlag.

Talbot, LM, WJA Payne, HP Ledger, LD Verdcourt, and MH Talbot. 1965. The meat production potential of wild animals in Africa. A review of the biological knowledge. Technical Communication No. 16, Commonwealth Bureau Animal Breeding and Genetics vol 16. Edinburgh: Commonwealth Agricultural Bureaux.

Taylor, S. 2002. Save Valley conservancy [film]. Zimbabwe: 60 minutes.

Taylor, R. 2009. Community based natural resource management in Zimbabwe: the experience of CAMPFIRE. Biodiversity and Conservation 18: 2563-2583.

Taylor, RD, and RB Martin. 1987. Effects of veterinary fences in Zimbabwe. Environmental Management 11(3): 327-334.

Taylor, RD, and BH Walker. 1978. Comparison of vegetation use and herbivore biomass on a Rhodesian game and cattle ranch. Journal of Applied Ecology 15: 565-581.

Vincent, V, and RG Thomas. 1961. An agricultural survey of southern Rhodesia. Salisbury: Federation of Rhodesia and Nyasaland. 2 Volumes.

Walker, BH (ed.). 1987. Determinants of tropical savannas. Oxford: IRL

Walker, B, CS Holling, SR Carpenter, and Ann Kinzig. 2004. Resilience, adaptability and transformability in socialecological systems. Ecology and Society 9(2): 2-10.

Williams, TO. 1993. Livestock pricing policy in sub-Saharan Africa: objectives, instruments and impact in five countries. Agriculture Economics 8: 139-159.

doi:10.1186/2041-7136-2-18

Cite this article as: Child et al:: The economics and institutional economics of wildlife on private land in Africa.

Pastoralism: Research, Policy and Practice 2012 2:18.

\section{Submit your manuscript to a SpringerOpen ${ }^{\circ}$ journal and benefit from:}

- Convenient online submission

- Rigorous peer review

- Immediate publication on acceptance

- Open access: articles freely available online

- High visibility within the field

- Retaining the copyright to your article

Submit your next manuscript at $\boldsymbol{\sim}$ springeropen.com 